\title{
Tropospheric ozone production related to West African city emissions during the 2006 wet season AMMA campaign
}

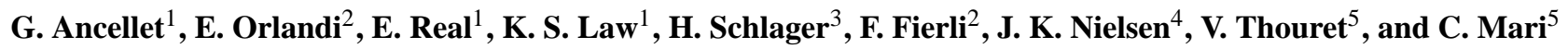 \\ ${ }^{1}$ UPMC Univ. Paris 06, UMR8190, CNRS/INSU, LATMOS-IPSL - Université Versailles, St-Quentin, France \\ ${ }^{2}$ ISAC-Institute for Atmospheric Sciences and Climate, National Research Council, Bologna, Italy \\ ${ }^{3}$ DLR Institut für Physik der Atmosphäre, Oberpfaffenhofen, Germany \\ ${ }^{4}$ Danish Meteorological Institute, Lyngbyvej, Denmark \\ ${ }^{5}$ Université de Toulouse, CNRS, LA (Laboratoire d'Aérologie), Toulouse, France
}

Received: 1 September 2010 - Published in Atmos. Chem. Phys. Discuss.: 10 November 2010

Revised: 22 June 2011 - Accepted: 27 June 2011 - Published: 5 July 2011

\begin{abstract}
During African Monsoon Multidisciplinary Analyses (AMMA) airborne measurements of ozone, $\mathrm{CO}$ and nitrogen oxides $\left(\mathrm{NO}_{\mathrm{x}}\right)$ were collected by French and German Falcon aircraft near three cities in West Africa (Cotonou, Niamey and Ouagadougou). They have been analysed to identify the good conditions to observe ozone plumes related to city emissions during the monsoon season. Results show that an $\mathrm{O}_{3}$ increase of $40-50 \mathrm{ppbv}$ above the summer average concentration took place during two specific events: one near Cotonou on the coast of the Gulf of Guinea, and the other near Niamey in the Sahel region. In both cases a high level of $\mathrm{NO}_{\mathrm{x}}(3-5 \mathrm{ppbv})$ is related to the ozone production. Air mass transport simulations with FLEXPART and a tracer simulation with the BOLAM mesoscale model shows that Southern Hemisphere biomass burning emissions are always at higher altitude $(>3 \mathrm{~km})$ compared to the city emissions. In Niamey and Ouagadougou, the daily variability of ozone and CO correlates with the FLEXPART analysis showing the role of air mass stagnation near the city for 1-2 days and advection of emissions from the vegetated areas. Absence of ozone enhancements for high $\mathrm{CO}$ values can be explained by the occurrence of deep convection near the city. In the Sahel region, convection must be accounted for to understand the small number of observed ozone plumes but also to explain the high level of $\mathrm{NO}_{\mathrm{x}}$ in the $3-5 \mathrm{ppbv}$ range, due to increasing soil emissions after rainfall. To verify that daily ozone production can reach $20 \mathrm{ppbv} \mathrm{day}^{-1}$ for
\end{abstract}

Correspondence to: G. Ancellet (gerard.ancellet@upmc.fr) the $\mathrm{NO}_{\mathrm{x}}$ and $\mathrm{CO}$ conditions encountered near West African cities, a simulation of the CiTTyCAT Lagrangian model was conducted using the observed average chemical composition reported by other aircraft during AMMA. Such ozone production is possible for $\mathrm{NO}_{\mathrm{x}}$ levels up to $5 \mathrm{ppb}$ showing that West African cities are potentially significant sources of tropospheric ozone.

\section{Introduction}

According to UNEP (United Nations Environment Programme), Africa will have the fastest population growth rate in the world between 2000 and 2050, twice the rate of any other region during that time. Given their relatively low industrial development, air pollution in west African countries is not as widespread as in other regions of the world. However, in most populous cities, long-term exposure to poor-air quality has been found to be a severe health issue for the population. Africa is also known to contribute to ozone formation at the global scale mainly because of large amounts of biomass burning (Andreae and Merlet, 2001; Thouret et al., 2009), biogenic emissions (soil and vegetation) (Guenther et al., 2006; Stewart et al., 2008) and lightning $\mathrm{NO}_{\mathrm{x}}$ (Schumann and Huntrieser, 2007). Anthropogenic emissions related to fossil fuel combustion are generally considered as a regional problem (Aghedo et al., 2007). For example large cities like Lagos $\left(6^{\circ} 35^{\prime} \mathrm{N}, 3^{\circ} 2^{\prime} \mathrm{E}\right)$ along the coast of the Guinea Gulf are known to influence air quality and ozone production at local scale (Baumbach et al., 1995; Minga et al., 2010). Most recent emission data bases still

Published by Copernicus Publications on behalf of the European Geosciences Union. 
underestimate this contribution and are needed for accurate modelling of aerosol and trace gas distributions in this region (Liousse et al., 2010).

Although many papers have discussed the link between tropospheric ozone total column variability over West Africa and tropical Atlantic with biomass burning emissions (Thouret et al., 2009; Sauvage et al., 2007b; Thompson et al., 2000), there are few papers about city plume studies in this region. Minga et al. (2010) showed that during the dry season very large amounts of $\mathrm{O}_{3}$ can be found near Cotonou $\left(2^{\circ} 26^{\prime} \mathrm{E}, 6^{\circ} 60^{\prime} \mathrm{N}\right)$ due to the Lagos industrial area. Hopkins et al. (2009) also discussed the impact of the city of Lagos on ozone precursor emission using the data of the UK BAe-146 aircraft recorded during a circular flight around the city in July 2006. The emission levels for $\mathrm{NO}_{\mathrm{x}}$ and $\mathrm{CO}$ were found to be high enough to characterise the Lagos area as a polluted megacity, but the fate of these emissions for photochemical ozone production is not discussed in that study. Thus ozone production due to African megacities remains poorly documented especially during the wet season.

In this paper, our objective is to analyse aircraft data collected near three major cities: Cotonou, $2^{\circ} 26^{\prime} \mathrm{E}, 6^{\circ} 60^{\prime} \mathrm{N}$, Niamey, $2^{\circ} 05^{\prime} \mathrm{E}, 13^{\circ} 32^{\prime} \mathrm{N}$ and Ouagadougou, $1^{\circ} 32^{\prime} \mathrm{W}$, $12^{\circ} 22^{\prime} \mathrm{N}$, focusing on ozone production and the respective impact of anthropogenic emission and Southern Hemisphere (SH) biomass burning. They have been analysed to identify the good conditions to observe ozone plumes related to city emissions during the monsoon season. Aircraft data has the great advantage of providing vertical profiles of $\mathrm{O}_{3}$ and its precursors, limited to $\mathrm{NO}_{\mathrm{x}}$ and $\mathrm{CO}$ observations in this work. The aircraft were deployed during the African Monsoon Multidisciplinary Analyses (AMMA) campaign in July-August 2006 aimed at studying the role of convection on the atmospheric composition (Reeves et al., 2010). During the wet season, photochemical $\mathrm{O}_{3}$ production in the lower troposphere is limited by frequent fast vertical mixing (Chatfield and Delany, 1990), but during this season there is a better altitudinal decoupling of the respective influence of emissions from biomass burning and from African cities on the regional ozone production. Thouret et al. (2009) showed that the advection of biomass burning from the SH during the wet season is seen at higher altitudes $(3-5 \mathrm{~km})$ than during the dry season $(1-3 \mathrm{~km})$.

The paper is structured as follows. In Sect. 2, we introduce the meteorological context and differences between Cotonou and Niamey/Ouagadougou. In Sect. 3, the aircraft observations are presented and discussed. Different model results are used in Sect. 4 (i) to demonstrate that we are able to separate the $\mathrm{O}_{3}$ plumes from city emissions and those related to biomass burning, (ii) to discuss the good meterological conditions for $\mathrm{O}_{3}$ plume formation and (iii) to assess an upper limit of the $\mathrm{O}_{3}$ photochemical production in the city plumes considering the chemical observations available for this campaign. In Sects. 4.1 and 4.2, the air mass transport is studied using Lagrangian model simulations (FLEXPART), to identify whether air masses stayed long enough under the influence of urban emissions to increase $\mathrm{O}_{3}$ concentrations or if they were influenced by other emissions (Southern Hemisphere, tropical forest). In Sect. 4.3, the vertical structure of ozone in Cotonou is discussed using a tracer simulation from the mesoscale model (BOLAM) to show that biomass burning emissions can be distinguished from the city emissions. The photochemical $\mathrm{O}_{3}$ production is discussed in Sect. 4.4 using the chemical box model CiTTyCAT. Finally, we discuss the representativeness of the limited number of aircraft measurements in Sect. 5.

\section{Meteorological context and characteristics of the selected cities}

The synoptic situation over West Africa during the summer monsoon is characterised by the convergence of the Harmattan flux blowing from the Sahara desert to the gulf of Guinea and the monsoon fluxes advecting inland the maritime air masses. The main averaged characteristics of these two flows are shown in Fig. 1 for the $0-1 \mathrm{~km}$ and 3$4 \mathrm{~km}$ altitude layers during August 2006. The wind data are from the ECMWF reanalysis with assimilated AMMA soundings (Agusti-Panareda et al., 2009). Below $1 \mathrm{~km}$ the humid and relatively cold monsoon flow penetrated inland reaching Ouagadougou (Burkina Faso) and Niamey (Niger). Above $3 \mathrm{~km}$, the most striking features are the African Easterly Jet (AEJ), located north of $10^{\circ} \mathrm{N}$, with wind speed over $15 \mathrm{~m} \mathrm{~s}^{-1}$ (AEJ-N) and a similar wind flow south of the equator with wind speed up to $9 \mathrm{~m} \mathrm{~s}^{-1}$ (AEJ-S) (Parker et al., 2005; Tompkins et al., 2005). The AEJ-S interacted with the monsoon flow and played an important role in the interhemispheric transport of biomass burning pollution, while the AEJ-N limits the northward extent of such a transport (Mari et al., 2008). The role of the monsoon circulation on the regional ozone and $\mathrm{CO}$ distribution is discussed in Reeves et al. (2010), and in this paper we only consider the meteorological factors important for $\mathrm{O}_{3}$ production resulting from anthropogenic emissions.

According to the weather patterns in the lower troposphere, we distinguish two groups of cities: (i) Lagos or Cotonou mainly influenced by SH emissions and the Atlantic boundary layer chemical composition, (ii) Niamey and Ouagadougou, named hereafter the Sahelian cities which are mainly influenced by the northernmost part of the monsoon flow advecting biogenic emissions from forested regions to the south. This is why we analyse separately the Cotonou observations and the Niamey/Ouagadougou data set. Even though Niamey and Ouagadougou are similar with respect to the weather patterns, we expect different emission factors for these two cities considering their different population sizes (1.2 million for Ouagadougou and 700000 for Niamey). The RETRO anthropogenic emission inventory at $0.5^{\circ}$ resolution and with a monthly time resolution for year 


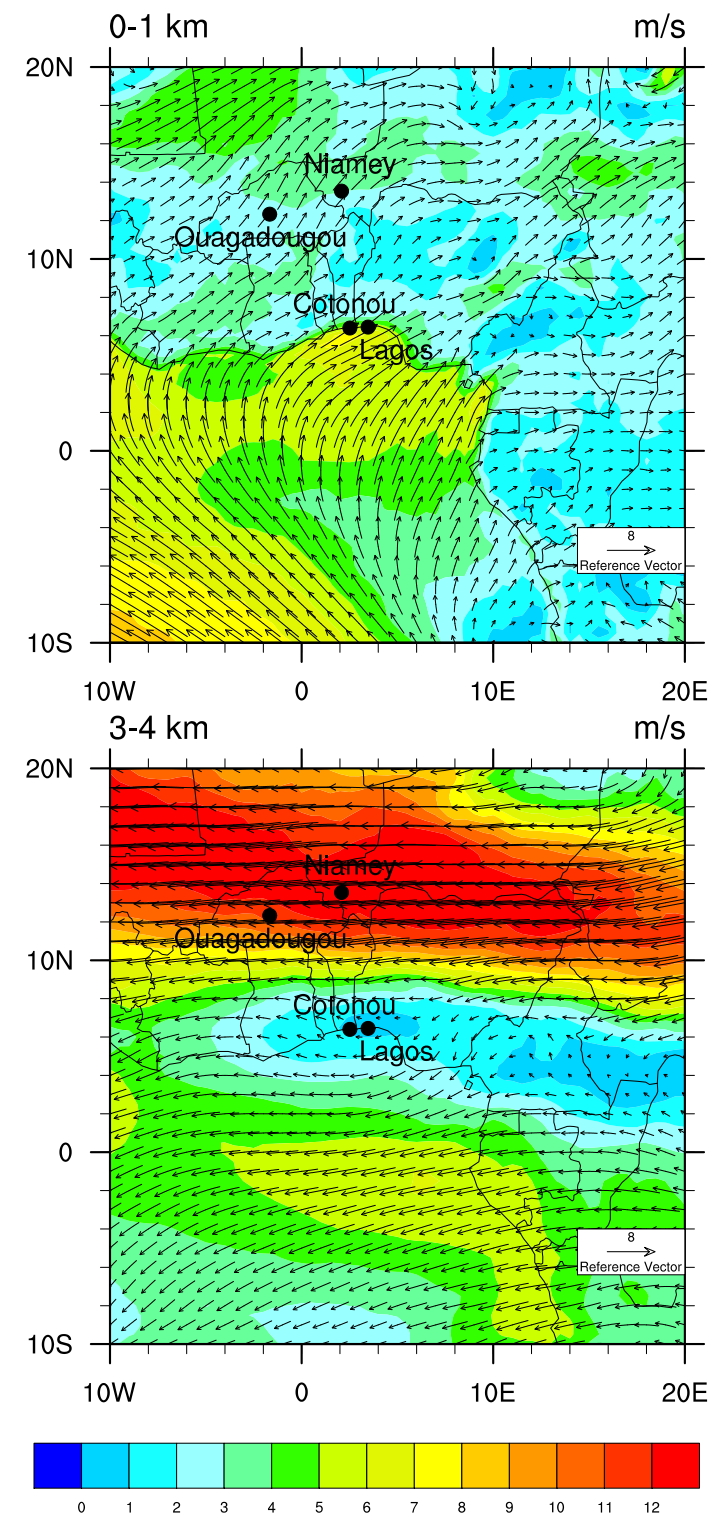

Fig. 1. Wind velocity $\left(\mathrm{m} \mathrm{s}^{-1}\right)$ and vectors from ECMWF reanalysis averaged over August 2006 for the 3-4 km (bottom), and 0-1 km (top) tropospheric layers.

2000 (http://retro.enes.org/) indeed shows CO fluxes three time more important in Ouagadougou than in Niamey (Table 1). During the wet season, numerous mesoscale convective systems (MCSs) can develop over West Africa with a strong impact on vertical mixing of $\mathrm{O}_{3}$ and $\mathrm{O}_{3}$ precursors (Reeves et al., 2010; Thouret et al., 2009). This is known to impact the ozone distribution over the whole troposphere, but also to control the timing of the low level ozone production. Therefore, vertical mixing needs to be taken in to account when discussing the data set.
Table 1. CO fluxes in $\mu \mathrm{g} \mathrm{m}^{-2} \mathrm{~s}^{-1}$ for the $0.5 \times 0.5^{\circ}$ grid cell containing each of the 4 West African cities where aircraft data are available. Data are from the RETRO inventory (see http://retro. enes.org/).

\begin{tabular}{lrrl}
\hline City & Longitude & Latitude & CO flux \\
\hline LAGOS & 3.396 & 6.453 & 5.5935 \\
COTONOU & 2.433 & 6.367 & 0.9672 \\
NIAMEY & 2.083 & 13.667 & 0.09242 \\
OUAGA & -1.533 & 12.370 & 0.3324 \\
\hline
\end{tabular}

\section{Aircraft data analysis}

\subsection{The data set}

The measurements used in this paper were recorded by the French and German Falcon aircraft (named FF20 and DF20 hereafter) when they flew at altitudes less than $3 \mathrm{~km}$ just after takeoff or before landing in one of the West African cities. The FF20 data were obtained near Cotonou ( 2 profiles) and near Niamey (11 profiles), while the DF20 data were collected near Ouagadougou (18 profiles). The chemical species discussed in this paper are mainly $\mathrm{O}_{3}, \mathrm{CO}$ and $\mathrm{NO}_{\mathrm{x}}$ measurements. The specific humidity is also used to described the Planetary Boundary Layer (PBL) structure, especially its diurnal evolution between takeoff and landing profiles. The FF20 and DF20 instruments are respectively described in Ancellet et al. (2009) and in Baehr et al. (2003). The $\mathrm{NO}_{\mathrm{x}}$ instrument on the FF20 experienced problems with an ozone leak during the AMMA campaign and $\mathrm{NO}_{\mathrm{x}}$ was only measured in Cotonou ( 2 profiles) and near Niamey on 19 and 20 August (4 profiles). The FF20 CO measurements required frequent zero monitoring and only 8 out of the 11 profiles are available near Niamey because the zero monitoring occurred during the aircraft landing. The DF20 did not measure $\mathrm{NO}_{\mathrm{x}}$ concentration, but NO. Since it is important to make the Ouagadougou data set comparable to the Niamey data, we have estimated the $\mathrm{NO}_{\mathrm{x}}$ from the measured $\mathrm{NO}$ and $\mathrm{O}_{3}$ concentrations assuming that (i) the $\mathrm{NO}_{\mathrm{x}}$ partitioning is only determined by the $\mathrm{NO}_{2}$ photolysis and $\mathrm{NO}+\mathrm{O}_{3}$ reaction (ii) the measured $\mathrm{NO}_{2}$ photolysis coefficient is of the order of $0.015 \mathrm{~s}^{-1}$. There is a $20-30 \%$ uncertainty in the $\mathrm{NO}_{\mathrm{x}}$ values but good enough to discuss the occurrence of polluted layers with high $\mathrm{NO}_{\mathrm{x}}$ values.

The dates and times of the available profiles near Niamey and Ouagadougou are summarised in Table 2. In both cities, 6-7 $\mathrm{O}_{3}$ profiles were obtained after 14:00 UT, i.e. when an $\mathrm{O}_{3}$ plume was more likely to be detected considering the strong diurnal cycle controlling the ozone concentrations in the PBL. This corresponds in both cases to 4-5 different days. So the two datasets are quite comparable. 
Table 2. List of the flights near Niamey (Niam.) and Ouagadougou (Ouag.).

\begin{tabular}{|c|c|c|c|c|}
\hline Day (UTC) & City & $\begin{array}{c}\text { Takeoff } \\
\text { UTC }\end{array}$ & $\begin{array}{c}\text { Landing } \\
\text { UTC }\end{array}$ & Species measured \\
\hline 1 August & Ouag. & & 1130 & $\mathrm{O}_{3}, \mathrm{NO}_{\mathrm{x}}, \mathrm{CO}$ \\
\hline 4 August & Ouag. & 0845 & 1215 & $\mathrm{O}_{3}, \mathrm{NO}_{\mathrm{x}}, \mathrm{CO}$ \\
\hline 6 August & Ouag. & 0930 & 1245 & $\mathrm{O}_{3}, \mathrm{NO}_{\mathrm{x}}, \mathrm{CO}$ \\
\hline 7 August & Ouag. & 1220 & 1515 & $\mathrm{O}_{3}, \mathrm{NO}_{\mathrm{x}}, \mathrm{CO}$ \\
\hline 11 August & Ouag. & 1450 & 1750 & $\mathrm{O}_{3}, \mathrm{NO}_{\mathrm{x}}, \mathrm{CO}$ \\
\hline 11 August & Niam. & & 1530 & $\mathrm{CO}^{2}$ \\
\hline 13 August & Ouag. & 1040 & 1400 & $\mathrm{O}_{3}, \mathrm{NO}_{\mathrm{x}}, \mathrm{CO}$ \\
\hline 13 August & Niam. & 1215 & 1530 & $\mathrm{O}_{3}, \mathrm{CO}^{1}$ \\
\hline 14 August & Niam. & 0630 & 0930 & $\mathrm{O}_{3}^{2}$ \\
\hline 15 August & Ouag. & 0915 & 1230 & $\mathrm{O}_{3}, \mathrm{NO}_{\mathrm{x}}, \mathrm{CO}$ \\
\hline 15 August & Niam. & 1230 & 1545 & $\mathrm{O}_{3}{ }^{1}, \mathrm{CO}^{1}$ \\
\hline 15 August & Ouag. & 1430 & 1700 & $\mathrm{O}_{3}, \mathrm{NO}_{\mathrm{x}}, \mathrm{CO}$ \\
\hline 16 August & Niam. & 1500 & 1700 & $\mathrm{O}_{3}, \mathrm{CO}^{1}$ \\
\hline 16 August & Ouag. & 1415 & 1700 & $\mathrm{O}_{3}, \mathrm{NO}_{\mathrm{x}}, \mathrm{CO}$ \\
\hline 17 August & Niam. & 0930 & 1245 & $\mathrm{O}_{3}, \mathrm{CO}^{1}$ \\
\hline 19 August & Niam. & 0915 & 1630 & $\mathrm{O}_{3}^{2}, \mathrm{NO}_{\mathrm{x}}, \mathrm{CO}^{2}$ \\
\hline 20 August & Niam. & 1400 & 1745 & $\mathrm{O}_{3}, \mathrm{NO}_{\mathrm{x}}, \mathrm{CO}$ \\
\hline
\end{tabular}

${ }^{1}$ measured during takeoff only, ${ }^{2}$ measured during landing only.

\subsection{Analysis of the Cotonou observations: a city on the southern coast}

Aircraft observations of $\mathrm{O}_{3}$ allow the analysis of the potential impact of anthropogenic pollutants on photochemical ozone production, provided that one can use vertical profiles east and west of the city of Cotonou. The aircraft data also offer the possibility to address the question of ozone production more precisely by using the vertical profiles of $\mathrm{CO}$ and $\mathrm{NO}_{\mathrm{x}}$. On 19 August 2006, the FF20 aircraft made a landing at 12:00 UT and a takeoff at 13:45 UT in Cotonou. The aircraft position around the city of Cotonou is shown on Fig. 2a when it was exploring the $0-3 \mathrm{~km}$ altitude range. Considering the small time difference between the two corresponding vertical profiles, the comparison provides a good estimate of the local scale horizontal gradients: southwest-northeast gradient below $3 \mathrm{~km}$ and northwest-southeast gradient above $3 \mathrm{~km}$. A dropsonde launched when flying over Cotonou at 10:41 UT (Fig. 2a) provides the observed wind vertical profile and the boundary layer structure can be examined using the water mixing ratio. The most remarkable feature looking at the difference between the east and west ozone profiles is the significant $\mathrm{O}_{3}$ increase ( $+50 \mathrm{ppbv}$ ) in the $1-3 \mathrm{~km}$ altitude range with mixing ratios reaching $80 \mathrm{ppbv}$ East of Cotonou (Fig. 2b). The water vapour mixing ratio profiles from the aircraft and the dropsonde show that the monsoon layer height extended up to $2.5 \mathrm{~km}$ and that it did not change very much during the time period 11:00 UT to 14:00 UT over the spatial domain corresponding to the aircraft measurements. Therefore the southwest-northeast ozone gradient is
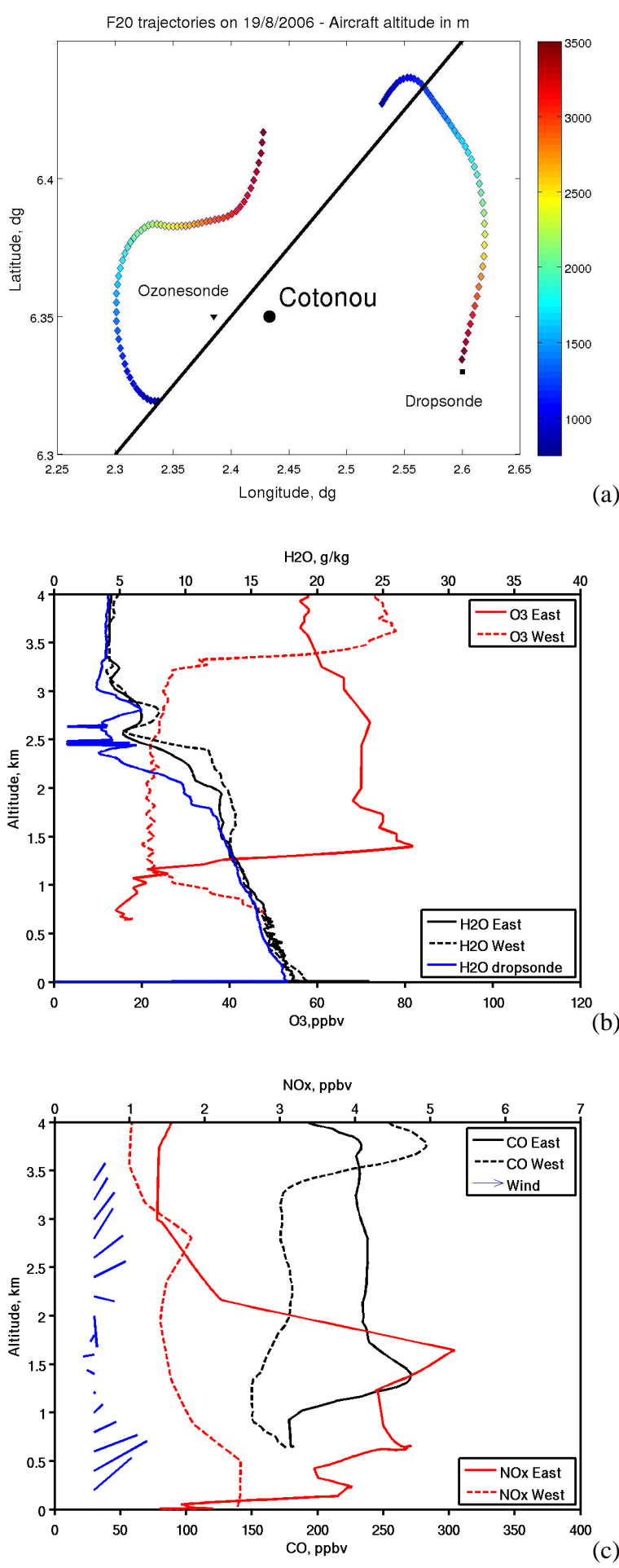

(c)

Fig. 2. (a) Map of the FF20 positions (colour scale is altitude in $\mathrm{m}$ ) around Cotonou on 19 August. The black solid line separates the ozone rich (East) and poor (West) area. (b) $\mathrm{O}_{3}, \mathrm{H}_{2} \mathrm{O}$ and (c) $\mathrm{CO}, \mathrm{NO}_{\mathrm{x}}$ vertical profiles measured by the $\mathrm{FF} 20$ west and east of Cotonou. The $\mathrm{H}_{2} \mathrm{O}$ dropsonde vertical profiles (b) describes the PBL evolution between 10:45 UT and 13:45 UT. The dropsonde wind direction vertical profile (c) shows the weakening of the southeasterly flow (base of the wind vector on the solid line). 
not related to a sharp discontinuity of the boundary layer height as observed sometimes near a coastline. Notice also that below $1 \mathrm{~km}$ and above $3 \mathrm{~km}$, the change in the ozone vertical distribution is completely different. The large ozone values above $3 \mathrm{~km}$ are now observed in the whole area above the coastline and are known to be related to advection of biomass burning from the SH (Mari et al., 2008). The effect of these emissions on $\mathrm{O}_{3}$ are already seen above $2.5 \mathrm{~km}$ in an ozone sonde profile taken on 17 August (see Sect. 5). When the aircraft approached the city from the north, $\mathrm{O}_{3}$ mixing ratios at altitudes below $1 \mathrm{~km}$ for the east profile were as low as the $1-$ to $3-\mathrm{km} \mathrm{O}_{3}$ values in the west profile $(20 \mathrm{ppbv})$. In contrast, $\mathrm{O}_{3}$ at altitudes below $1 \mathrm{~km}$ in the west profile increased to values near $50 \mathrm{ppbv}$ when the aircraft came closer to Cotonou. Thus, the black line in Fig. 2a represents the limit between the areas with high (East of the line) and low (West of the line) $\mathrm{O}_{3}$ concentrations. The low ozone values near Cotonou below $750 \mathrm{hPa}$ are also discussed in Reeves et al. (2010) showing the role of the weak ozone production over the ocean and the strong ozone sink over the vegetation area inland.

Looking now at the corresponding $\mathrm{CO}$ and $\mathrm{NO}_{\mathrm{x}}$ vertical profiles (Fig. 2c) for the east sector in the $1-3 \mathrm{~km}$ range, they also indicate larger $\mathrm{CO}$ (up to $250 \mathrm{ppbv}$ cooresponding to a 100 -ppbv increase) and $\mathrm{NO}_{\mathrm{x}}$ (up to $5 \mathrm{ppbv}$ corresponding to a 3-ppbv increase). Notice that the shorter lived compound, $\mathrm{NO}_{\mathrm{x}}$, followed more closely the structure of the boundary layer with a sharp gradient at $2.5 \mathrm{~km}$. The CO vertical profile is more comparable to the ozone profile. Thus, the ozone increase across the line of Fig. 2a corresponds to a concentration build-up longer than the daily time-scale of the boundary layer height evolution. Above $3 \mathrm{~km}$, the weak northwest-southeast CO gradient is consistent with the impact of the biomass burning emissions. Below $1 \mathrm{~km}$, the relative increase in $\mathrm{NO}_{\mathrm{x}}$ up to $2.5 \mathrm{ppbv}$ as the aircraft approached Cotonou again (see Fig. 2a) suggests that the 50 ppbv ozone mixing ratios seen in the lowest altitude range of the west profile are indeed related to the emissions from cities located on the coast. Notice also that the wind profile measured by the dropsonde shows the southwesterly direction of the monsoon flow explaining the southwest to northeast direction of the limit between the polluted and unpolluted air in Fig. 2a. There was also a layer of weak wind between 1 and $2.5 \mathrm{~km}$ suggesting that polluted city plumes stayed near Cotonou in this altitude range.

To address more explicitly the question of the respective influence of the emissions from the cities along the coast, namely Cotonou and Lagos, and biomass burning products advected aloft at altitudes higher than $3 \mathrm{~km}$, a more detailed analysis of the transport mechanisms is required. Before discussing this part of our work, it is important to study similar measurements near the two other cities less influenced by the SH emissions.

\subsection{Analysis of the Niamey and Ouagadougou observations: Sahelian cities}

All the $\mathrm{CO}, \mathrm{O}_{3}$ and $\mathrm{NO}_{\mathrm{x}}$ vertical profiles measured by the aircraft are shown in Fig. 3 for the two cities. In Niamey the $\mathrm{CO}$ vertical profiles show a daytime PBL extending generally up to $1.2 \mathrm{~km}$ (Fig. 3c). The same feature was obtained using the water vapour vertical profiles (not shown). Although the water vapour profiles indicate that the PBL vertical structure does not change very much from one day to the next, there is a significant variability in the $\mathrm{CO}$ mixing ratio ranging from $100 \mathrm{ppbv}$ to $400 \mathrm{ppbv}$ in the 0.5 to $1.5 \mathrm{~km}$ altitude range. The occurrence of low values indicates that city emissions were not large enough to maintain a constant $\mathrm{CO}$ level around 200 ppbv as was observed near the coast. Nevertheless, freshly polluted plumes were detected by the aircraft near Niamey as shown by the occurrence of high $\mathrm{CO}$ values in this altitude range. There were only 2 days with $\mathrm{NO}_{\mathrm{x}}$ vertical profiles (19 and 20 August) and they also show plumes with high $\mathrm{NO}_{\mathrm{x}}$ values in the $0.5-1.5 \mathrm{~km}$ altitude range during landing (Fig. 3e). $\mathrm{NO}_{\mathrm{x}}$ mixing ratios were less than in Cotonou but reached $3 \mathrm{ppbv}$ in the plumes.

In Ouagadougou, the $\mathrm{CO}$ and $\mathrm{NO}_{\mathrm{x}}$ (Fig. 3d and f) profiles show a slightly lower PBL top $(<1 \mathrm{~km})$. The CO variability within the PBL is less than in the Niamey data set with mixing ratios ranging between 100 and $250 \mathrm{ppbv}$. This is a good indication that no well defined polluted plumes advected away from the city at altitudes above $1 \mathrm{~km}$ were encountered by the aircraft. The mean $\mathrm{NO}_{\mathrm{x}}$ mixing ratios were of the order of $1 \mathrm{ppbv}$ near $1 \mathrm{~km}$, but values as large as $4-5 \mathrm{ppbv}$ were observed near the ground, especially on 16 August. The $1 \mathrm{ppbv} \mathrm{NO}_{\mathrm{x}}$ level is similar to the BAe146 aircraft average $\mathrm{NO}_{\mathrm{x}}$ vertical profile observed during the AMMA campaign in the $12^{\circ}-16^{\circ} \mathrm{N}$ latitude band (Saunois et al., 2009). Such a $\mathrm{NO}_{\mathrm{x}}$ mixing ratio range $(0.5-1.5 \mathrm{ppbv})$ is measured outside city plumes and it is related primarily to NO emission from recently wetted soil (Stewart et al., 2008).

In Niamey, the ozone values were generally lower than 35 ppbv in the free troposphere above the PBL as discussed in Reeves et al. (2010) and the day to day variability is low at this altitude (Fig. 3a). Within the PBL or near its maximum altitude, $\mathrm{O}_{3}$ mixing ratios reaching $50 \mathrm{ppbv}$ were observed in 3 profiles, especially on 16 August when $\mathrm{O}_{3}>70$ ppbv. This is very different from Cotonou where there was a positive ozone vertical gradient. This suggests that photochemical $\mathrm{O}_{3}$ production occurred within the PBL in Niamey and not above the $1.5 \mathrm{~km}$ because of the latitudinal decrease of ozone precursors due to biomass burning emissions. The day to day variability of the $\mathrm{O}_{3}$ and $\mathrm{CO}$ mixing ratios (Fig. 4a) shows that the largest probability of sampling the Niamey plume, i.e. with the largest $\mathrm{CO}$ values, was during the period 15 August to 17 August. More high $\mathrm{O}_{3}$ episodes were not observed probably because very specific conditions are required such as air mass stagnation around the city or significant addition of $\mathrm{NO}_{\mathrm{x}}$ emissions from wetted bare soil as 

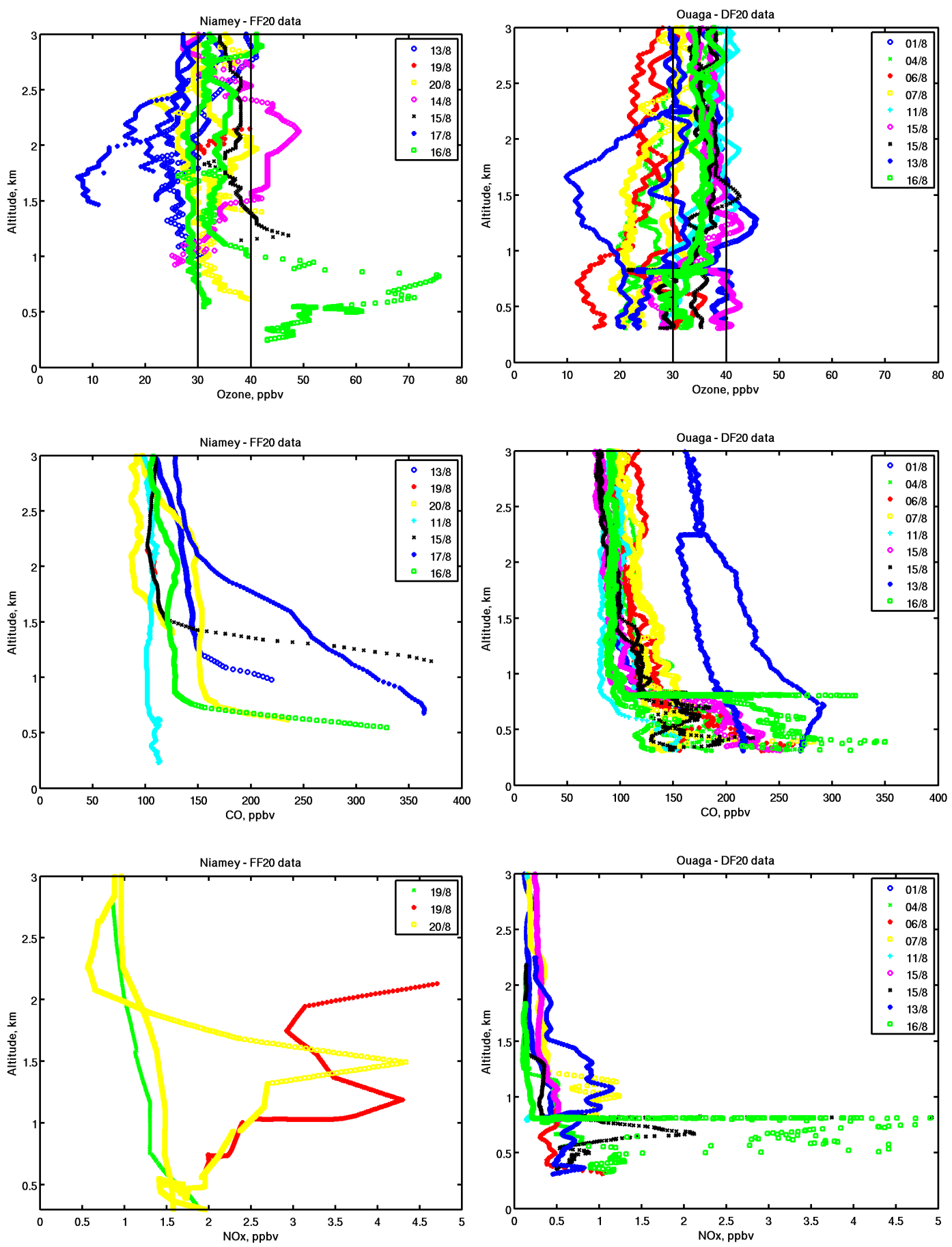

Fig. 3. Vertical profiles of $\mathrm{O}_{3}$ - top panels (a), (b) - $\mathrm{CO}$ - middle panels (c), (d) - and $\mathrm{NO}_{\mathrm{x}}$ - bottom panels (e), (f) - mixing ratio measured by the FF20 near Niamey (left) and the DF20 near Ouagadougou (right).

discussed by Saunois et al. (2009) using a regional model and observations. The role of the transport in the observed day to day variability is discussed more precisely in Sect. 4.2.

In Ouagadougou, the vertical ozone profiles (Fig. 3b) show a small variability around $30 \mathrm{ppbv}$ at all altitudes. This is consistent with less ozone produced by polluted plumes at altitudes $<1 \mathrm{~km}$. The slightly positive $\mathrm{O}_{3}$ vertical gradient is different from the Niamey data set and can be related to the more efficient ozone sink over the more vegetated situation in Ouagadougou. Notice also that according to Table 3, the DF20 flights often took place during the days with active convection increasing vertical mixing and preventing ozone 
Table 3. List of Mesoscale Convective System (MCS) derived from Meteosat satellite observations near Niamey and Ouagadougou.

\begin{tabular}{lll}
\hline Day & Position & Comments on MCS evolution \\
\hline 31 July & $2.5^{\circ} \mathrm{W}, 15^{\circ} \mathrm{N}$ & Travelling over Ouagadougou at 16:30 UT and growing during the day \\
4 August & $2.5^{\circ} \mathrm{W}, 14^{\circ} \mathrm{N}$ & North of Ouagadougou in the morning, decays after 09:00 UT but cloudy in the afternoon \\
6 August & $2^{\circ} \mathrm{E}, 13^{\circ} \mathrm{N}$ & Large MCS travelling west over Ouagadougou after 12:00 UT \\
7 August & $2^{\circ} \mathrm{E}, 13^{\circ} \mathrm{N}$ & A patchy MCS develops over Ouagadougou after 15:00 UT \\
11 August & $3^{\circ} \mathrm{E}, 13^{\circ} \mathrm{N}$ & Large MCS over Niamey in the morning and Ouagadougou after 12:00 UT \\
14 August & $2^{\circ} \mathrm{E}, 14^{\circ} \mathrm{N}$ & MCS arriving over Niamey at 12:00 UT and decays during the day \\
16 August & $2^{\circ} \mathrm{W}, 12^{\circ} \mathrm{N}$ & Small system developing over Ouagadougou during the day \\
17 August & $2^{\circ} \mathrm{E}, 15^{\circ} \mathrm{N}$ & Small system forming North of Niamey, decays during the day but cloudy in Niamey until 14:00 UT \\
\hline
\end{tabular}
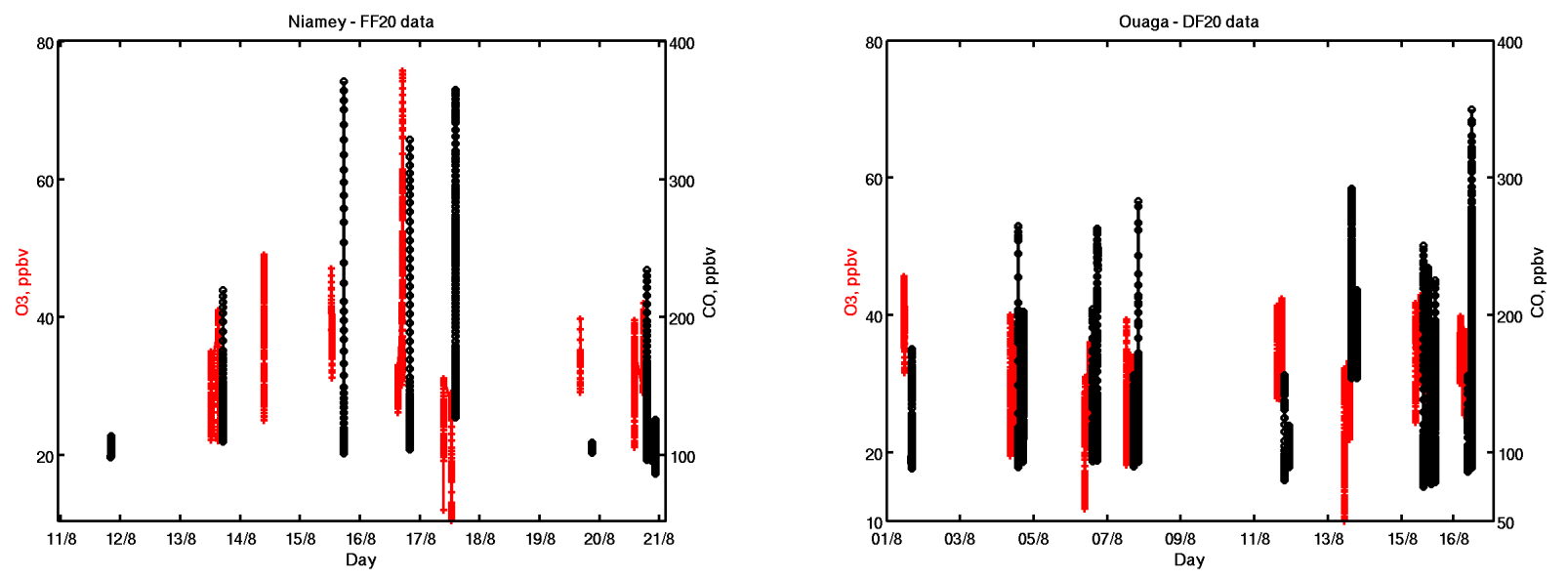

Fig. 4. Daily variability of $\mathrm{O}_{3}$ (red) and $\mathrm{CO}$ (black) mixing ratio range measured in the $0-3 \mathrm{~km}$ altitude range by the the FF20 near Niamey - left panel, (a) - and the DF20 near Ouagadougou - right panel, (b).

production (Chatfield and Delany, 1990; Reeves et al., 2010). The daily variability of the $\mathrm{O}_{3}$ or $\mathrm{CO}$ mixing ratios (Fig. 4b) confirms that there were no days with conditions favourable to photochemical $\mathrm{O}_{3}$ production near Ouagadougou, even on 16 August when large $\mathrm{NO}_{\mathrm{x}}$ and $\mathrm{CO}$ are encountered. Subsequent $\mathrm{O}_{3}$ production could have still occurred downwind.

To explain the Niamey $\mathrm{O}_{3}$ production on 16 August 2006, we unfortunately do not have $\mathrm{NO}_{\mathrm{x}}$ mixing ratio measured by the FF20. However, the $\mathrm{NO}_{\mathrm{x}}$ measured on 19 and $20 \mathrm{Au}-$ gust (Fig. 3e) show that values of the order of 3 ppbv can be found in the afternoon in the upper part of the PBL. Since CO is not very high on 19 and 20 August (Fig. 4a), we expect even higher $\mathrm{NO}_{\mathrm{x}}$ values for the days corresponding to the polluted plume crossing (15 to 17 August). Notice that $\mathrm{NO}_{\mathrm{x}}$ can be as large as $5 \mathrm{ppbv}$ in Ouagadougou on $16 \mathrm{Au}-$ gust, showing that high $\mathrm{NO}_{\mathrm{x}}$ can be also recorded in Sahelian cities. Since Stewart et al. (2008) shows that a significant fraction of the 5 ppbv $\mathrm{NO}_{\mathrm{x}}$ level found in West Africa can be attributed to the wetted soil emissions (up to $1.5 \mathrm{ppbv}$ ), it is important to consider also the variability of the convective activity. This was at a maximum in the first half of August (Table 3) and slowed down at least over western Niger only after 14 August. So indeed soil $\mathrm{NO}_{\mathrm{x}}$ emissions must be considered during the period 15 August to 17 August in addition to the emissions from the city of Niamey. After 14 August, reductions in local cloudiness and precipitation could have also maintained high levels of $\mathrm{NO}_{\mathrm{y}}, \mathrm{HCHO}, \mathrm{NO}_{2}$ photolysis and production of $\mathrm{HO}_{\mathrm{x}}$ radicals. This could explain the observed ozone increase of $30 \mathrm{ppbv}$ in the polluted plume on 16 August. To explain the low ozone values observed again on 17 August in Niamey, one can notice that new convective activity on this day (Table 3) limited further $\mathrm{O}_{3}$ plume formation even though the aircraft still measured high $\mathrm{CO}$ mixing ratios. Vertical mixing during convective episodes will limit the lifetime of ozone plumes forming near the top of the PBL. The influence of convection and related mixing on surface $\mathrm{O}_{3}$ in Senegal is discussed in Grant et al. (2008). The impact of $\mathrm{NO}_{\mathrm{y}}$ removal processes on $\mathrm{O}_{3}$ photochemistry is discussed in Sanderson et al. (2008). The role of the synoptic scale transport must be also accounted for to explain the ozone variability during the 15 August to 17 August period. This will be analyzed in the Sect. 4.

To support the role of the efficient $\mathrm{O}_{3}$ sink over the vegetation area south of Niamey, one can use all the $\mathrm{O}_{3}$ aircraft 


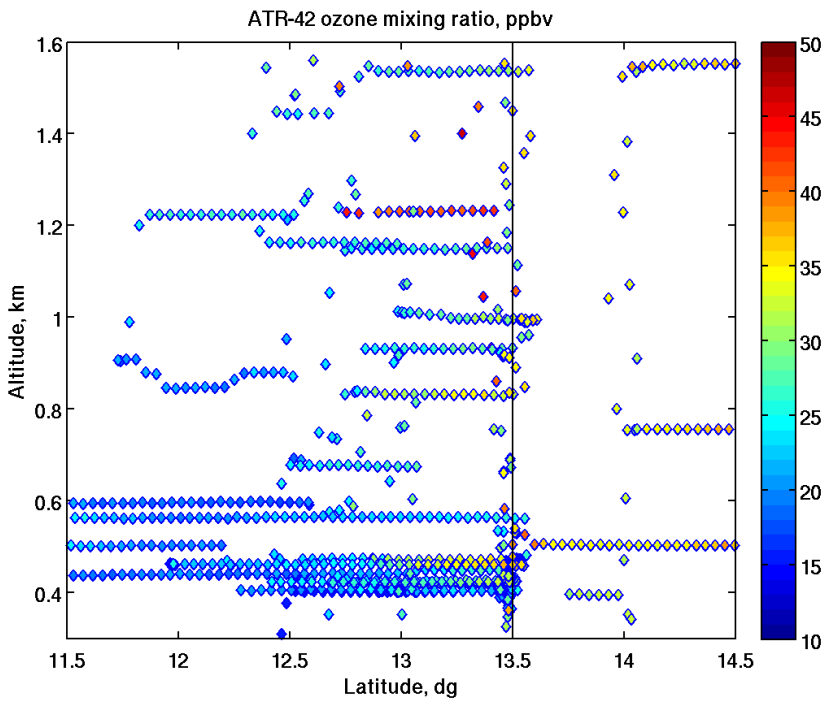

Fig. 5. Meridional $\mathrm{O}_{3}$ mixing ratio vertical cross section derived from the ATR-42 flights in August 2006 near Niamey, the position of which is marked by the black line.

measurements performed on-board another French aircraft (ATR-42) which often flew in the $11.5^{\circ}$ to $14.5^{\circ}$ latitude band at low altitude level around Niamey during the same time period (11 to 19 August 2006). The average meridional cross-section (Fig. 5) clearly shows the low $\mathrm{O}_{3}$ mixing ratios $(<30 \mathrm{ppb})$ south of Niamey at altitudes below $1 \mathrm{~km}$. Higher values observed near and to the north of Niamey illustrate the combined role of city and soil $\mathrm{NO}_{\mathrm{x}}$ emission in the $\mathrm{O}_{3}$ budget as discussed in Reeves et al. (2010).

To summarise, the Sahelian cities also exhibit the potential for ozone production in the city plumes. Differences in anthropogenic emissions between Ouagadougou and Niamey should lead to more $\mathrm{O}_{3}$ pollution episodes in the former. This does not seem to be the case, so factors other than the magnitude of emissions are needed to explain the differences in $\mathrm{O}_{3}$ concentration:

- The occurrence in Niamey of a non-convective period lasting at least 2 or 3 days to reduce vertical mixing and wet removal of $\mathrm{NO}_{\mathrm{x}}$ reservoir species in $\mathrm{NO}_{\mathrm{y}}$ but following very active convection and related precipitation necessary to increase $\mathrm{NO}_{\mathrm{x}}$ soil emissions.

- Significant vegetation cover around Ouagadougou increasing local ozone surface dry deposition.

Different large scale transport mechanisms may also be responsible for the daily variability observed in both places and for the difference of the ozone enhancement in Niamey and Ouagadougou. In the following section we address these issues.

\section{Model results}

The first objective of this section is to provide a characterisation of air mass transport using the FLEXPART Lagrangian particle dispersion model. Other modelling work performed in this study were aimed at demonstrating that: (1) regional ozone production near the coast is not related to the $\mathrm{SH}$ biomass burning at altitudes $<3 \mathrm{~km}$, (2) the chemical composition of the air masses influenced by the city emissions is consistent with $\mathrm{O}_{3}$ mixing ratios reaching $70-80 \mathrm{ppbv}$ in a polluted plume staying for two days in the area influenced by these emissions. To answer the first question, a simulation using a mesoscale model was needed to reproduce the detailed dynamical processes of the monsoon layer. The advantage of using a mesoscale model to address the complex interaction of emissions and dynamics in the monsoon layer has been demonstrated by several studies (Vizy and Cook, 2002; Sauvage et al., 2007a; Delon et al., 2008). The second question has been addressed, albeit in a fairly simplistic manner, using runs with a chemical box model initialised with observations. A similar approach was used in the Minga et al. (2010) work with a chemical box model (0D model) to study the ozone production downwind of Lagos and to study ozone production in biomass burning plumes (Real et al., 2010)

\subsection{Transport of the air masses in Cotonou (19 August)}

The FLEXPART model version 6 (Stohl et al., 1998, 2002) driven by 6-hourly ECMWF re-analyses (T213L91) interleaved with operational forecasts every $3 \mathrm{~h}$, was run for 5 days in a backward mode by releasing 2000 particles in 2 boxes corresponding to the altitude range $2-2.5 \mathrm{~km}$ and $3.5-4 \mathrm{~km}$. The horizontal extent of the box was $1^{\circ} \times 1^{\circ}$ around the city of Cotonou. FLEXPART used ECMWF analyses with 91 model levels and a resolution of $0.5^{\circ}$. The initial version of the model included the computation of potential vorticity $(\mathrm{PV})$ for each air parcel. The fraction of particles with $\mathrm{PV}>2 \mathrm{PVU}\left(1 \mathrm{PVu}=10^{-6} \mathrm{~K} \mathrm{~kg}^{-1} \mathrm{~m}^{2}\right)$ was calculated for each time step to estimate the probability of transport from or into the stratosphere. Previous studies have shown that a fraction larger than $20 \%$ encountered during a 5-days time period corresponds to a significant influence of the stratosphere-troposphere exchange (STE) for the air mass at the release time (Colette and Ancellet, 2006). We modified the FLEXPART model to introduce the calculation of the fraction of particles originating below an altitude of $3 \mathrm{~km}$, for two areas corresponding to different emissions of ozone precursors and $\mathrm{CO}$ : the $\mathrm{SH}$ (latitude $<0^{\circ} \mathrm{N}$, longitude $<40^{\circ} \mathrm{E}$ ) for the biomass burning emission, a $1^{\circ}$ latitude band along the coast line of the Gulf of Guinea (latitude $\in\left[6^{\circ} \mathrm{N}, 7^{\circ} \mathrm{N}\right]$ ) for the anthropogenic emissions. The upper tropospherelower stratosphere (UTLS) fraction was defined as the particles coming from altitudes above $8 \mathrm{~km}$ and latitudes $>8^{\circ} \mathrm{N}$. These fractions are shown as a function of time in Fig. 6. For the layer with a release between $2-2.5 \mathrm{~km}$, i.e. corresponding 


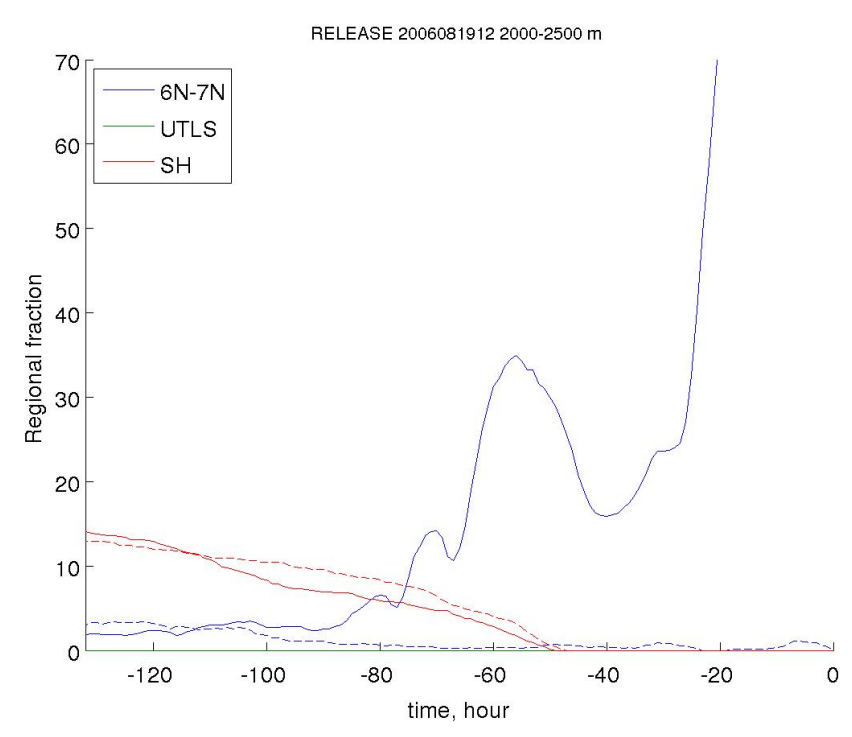

Fig. 6. Fraction of particles being in 3 different regions (see text for the definition of the regions) at each time step of backward FLEXPART runs for 2 releases above Cotonou in the altitude range 2.0 $2.5 \mathrm{~km}$ (solid line) and $3.5-4.0 \mathrm{~km}$ (dotted line). The UTLS fraction $(>8 \mathrm{~km})$ is always negligible.

to the layer with the southwest-northeast positve ozone gradient, the fraction of particles remaining in the coastal region is high for at least 3 days, while the transport from the $\mathrm{SH}$ remains weak (fraction $<10 \%$ ), even after 5 days. For the layer above $3 \mathrm{~km}$, local emissions near the coast have little influence compared to biomass burning emissions from the $\mathrm{SH}$, even though the fraction from the $\mathrm{SH}$ remains of the order of $10 \%$. The UTLS fraction is always very small ruling out the downward transport of stratospheric ozone, but showing also the limited role of the upper troposphere lightning $\mathrm{NO}_{\mathrm{x}}$ sources (Huntrieser et al., 2008) in the $\mathrm{NO}_{\mathrm{x}}$ concentrations below $3 \mathrm{~km}$. Therefore, the FLEXPART simulation shows that the low level southwest-northeast positive ozone gradient is largely related to local emissions near the coast.

\subsection{Transport of air masses in Niamey and Ouagadougou}

FLEXPART was also run in a backward mode for two boxes located above Niamey and Ouagadougou corresponding to the altitude range $0.5-1.5 \mathrm{~km}$. We again release 2000 particles in the $500 \mathrm{~m} \times 1^{\circ} \times 1^{\circ}$ boxes. The fraction at a given time step in two specific regions were also calculated: the $1^{\circ}$ latitude band around Niamey or Ouagadougou and the area with more vegetation, i.e. at latitudes $<10^{\circ}$. A large fraction in the first region (named city fraction hereafter) points to the influence of local anthropogenic emissions and also possibly soil $\mathrm{NO}_{\mathrm{x}}$ emissions provided that the stagnation took place after a convective period. A large fraction in the second region (named southern region fraction hereafter) is useful to determine how advection of biogenic emissions from the forest may change the ozone production (i.e. by increasing isoprene or terpene plant emissions and by changing the $\mathrm{HO}_{\mathrm{x}}$ radical chemistry). Enhancements in ozone production in a city plume at mid-latitudes have been previously observed when a plume mixed with background air strongly influenced by biogenic species (Derognat et al., 2003). The daily variability of the FLEXPART fraction of particles staying in the $1^{\circ}$ latitude band around the city and the fraction of particles influenced by the land emission south of $10^{\circ} \mathrm{N}$ are reported in Fig. 7. The city fraction is given $24 \mathrm{~h}$ before the observations as it is the minimum time period to obtain a measurable ozone enhancement due to city emissions. The southern region fraction is given $48 \mathrm{~h}$ before the observations as a longer time period reduces the lifetime of the ozone precursors from biogenic emission.

For Niamey, results show that there are 3 days with city fractions $>20 \%: 11,15$, and 16 August. The southern region fraction becomes significant after August 14 (>30\%) while 16 August is the only day with a stagnation of the air mass near Niamey following advection from the southern region, i.e. the optimum air mass transport conditions for $\mathrm{O}_{3}$ production. This is consistent with the aircraft observations showing the largest ozone enhancements on 16 August in Niamey.

For Ouagadougou, 11 August is the only day with a fraction $>20 \%$ in the city latitude band $24 \mathrm{~h}$ before the measurements. But, it is also the day when the northward transport was smallest $(<10 \%)$ and when there was a strong MCS with frequent overcast skies and mixing during the day. The influence of advection from latitudes $<10^{\circ}$ is often very high and even dominates the air mass composition on 4 and 6 August. This makes the Ouagadougou vertical profiles more representative of photochemical conditions found above the forest and so less impacted by local city emissions. These findings are consistent with the absence of elevated ozone values and moderate $\mathrm{NO}_{\mathrm{x}}$ mixing ratios in the DF20 flights compared to the Niamey FF20 flights.

While it is not shown in Fig. 7, the UT air mass fraction is also calculated with the same conditions used in the Cotonou simulation. Results are similar with a negligible influence of transport from the upper troposphere in both cities at altitudes near $1 \mathrm{~km}$.

In Sect. 3.3, we discussed the role of surface ozone deposition and convection in the analysis of the differences between Niamey and Ouagadougou observations, but the FLEXPART analysis also shows that specific synoptic scale transport conditions are also needed to explain the occurrence of ozone rich plumes near Niamey, i.e. the stagnation of air for more than $24 \mathrm{~h}$ near the city after advection from the forest region in order to increase the influence of biogenic emissions. 

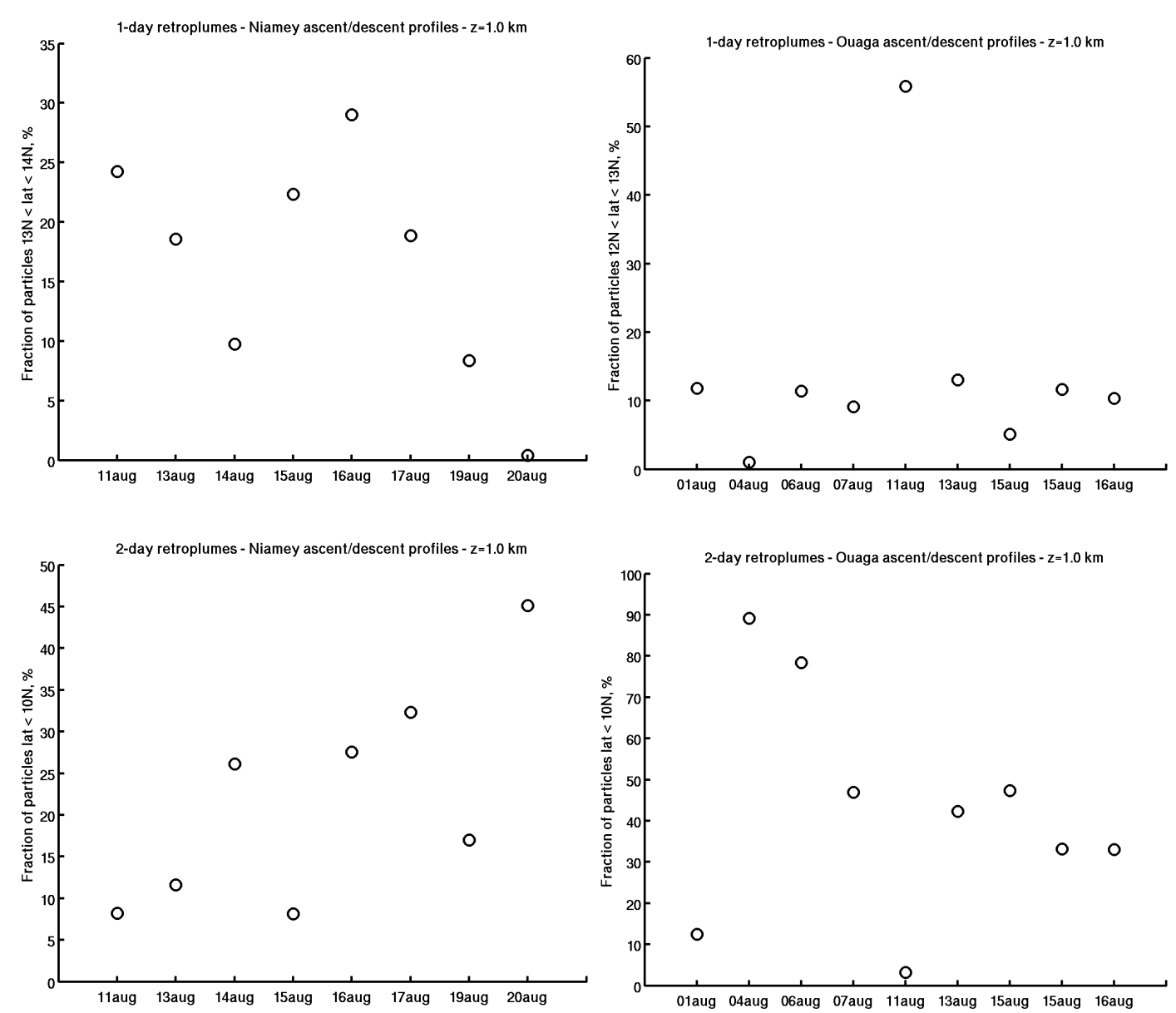

Fig. 7. Daily variability of local stagnation and northward transport from the forest using backward FLEXPART runs with releases at observation time t0 and in the altitude range $0.5-1.5 \mathrm{~km}$ above Niamey (right column) and Ouagadougou (left column). Top panels (a), (b): is the fraction of particles remaining within the 1olatitude band around the city at t0-1 day. Bottom panels (c), (d): is the fraction of particles coming from latitudes $<10^{\circ} \mathrm{N}$ at t0-2 days.

\subsection{BOLAM model results}

\subsubsection{Mesoscale model description and simulations set-up}

BOLAM (BOlogna Limited Area Model) is a limited-area meteorological model based on primitive equations in the hydrostatic approximation. Prognostic variables (horizontal wind components, potential temperature, specific humidity and surface pressure) are defined on hybrid coordinates and are distributed on a non-uniformly spaced Lorenz grid. It includes a microphysical scheme that has five prognostic variables (cloud water, cloud ice, rain, snow and graupel), as derived from the one proposed by Schultz (1995). Deep convection is parameterized with the scheme of KainFritsch (Kain, 2004). Vertical diffusion is modelled using the mixing-length assumption and the explicit prediction of turbulent kinetic energy (Zampieri et al., 2005). Further details of the model are provided in Malguzzi et al. (2006).
Here, the mesoscale model BOLAM was used to simulate the transport of southern hemispheric biomass burning and regional anthropogenic emissions over West Africa. To take into account the different spatial and temporal scales involved in the transport, two simulations were performed: a three month run for biomass burning emissions and a shorter and higher resolution run for anthropogenic emissions. For both simulations ECMWF AMMA re-analyses have been used as initial and boundary conditions (Agusti-Panareda et al., 2009).

1. Local anthropogenic emissions simulation (hereafter $8 \mathrm{~km}$-anthro) characteristics are as follows: the simulation covered a period of 5 days, starting on 00:00 UTC of 15 August 2006. The horizontal grid resolution was $0.07^{\circ} \times 0.07^{\circ}$ (around $8 \times 8 \mathrm{~km}$ ) and 60 vertical levels used with 21 levels below $3 \mathrm{~km}$ and the lowest level at $65 \mathrm{~m}$. The domain's limits were longitude $=[-2.8$, 7.6] and latitude $=[1.1,11.5]$. The tracer field was initialised to zero and $\mathrm{CO}$ fluxes from the RETRO 

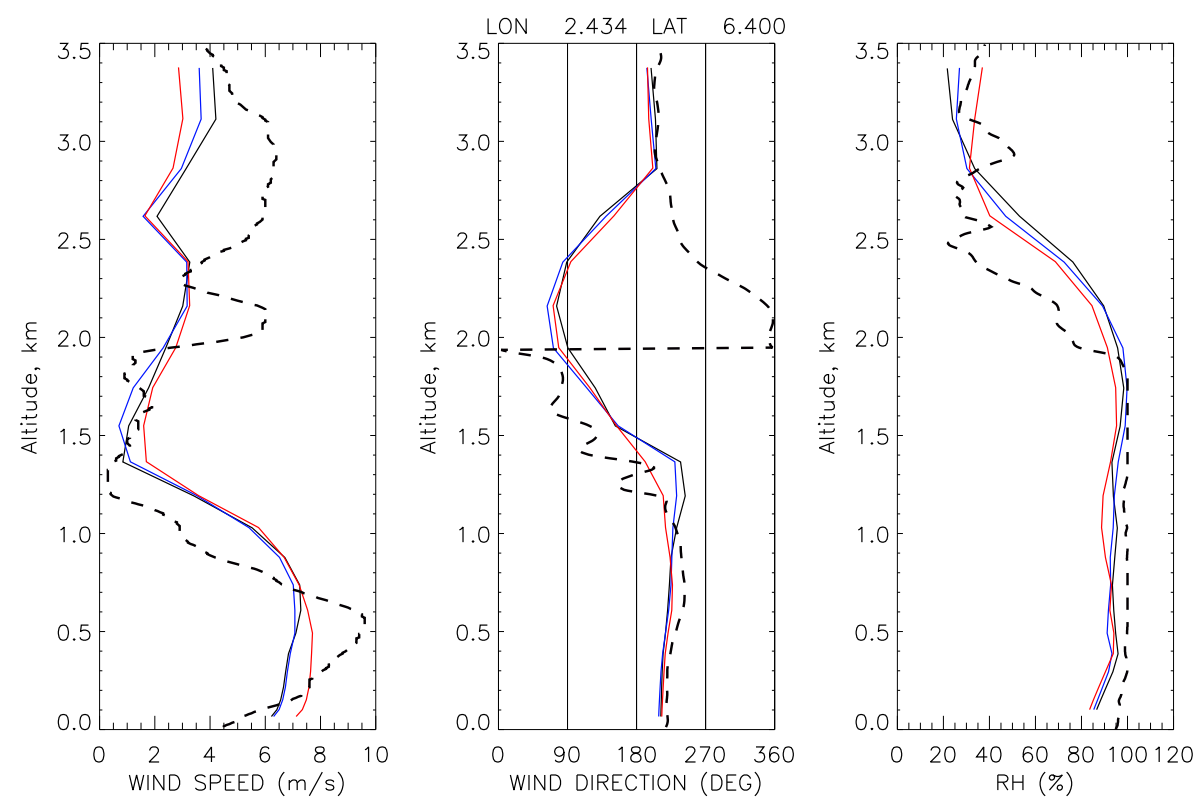

Fig. 8. Wind speed, wind direction and relative humidity from dropsonde launched at 10:40 UTC (black dashed) and from the $8 \mathrm{~km}$-anthro BOLAM simulation at 10:00 UTC (black), 12:00 UTC (blue) and 14:00 UTC (red) on 19 August over Cotonou.

inventory (Table 1) were used to inject anthropogenic emissions into the lowest model layer during the whole simulation. High values for emissions are reported for Lagos, while the overall area encompassing Cotonou and Lagos reaches more than $6.5 \mu \mathrm{g} \mathrm{m}^{-2} \mathrm{~s}^{-1}$ ). The CO tracer underwent exponential decay with a lifetime of 20 days imposed to match the lifetime of $\mathrm{CO}$ in the troposphere (Mauzerall et al., 1998).

2. The biomass burning emissions simulation (hereafter $24 \mathrm{~km}-\mathrm{bb}$ ) characteristics are as follows: the simulation started on 15 June and ended on 31 August 2006. Meteorological fields were re-initialised on 1 July and 1 August. The horizontal grid resolution was $0.216^{\circ} \times 0.216^{\circ}$ (around $24 \times 24 \mathrm{~km}$ ) and 38 vertical levels were used. The domain included both West Africa and the area of SH wild fires, domain's limits were longitude $=[-22,40]$ and latitude $=[-20,29]$. The tracer was injected up to $1 \mathrm{~km}$ altitude and 5-day averaged $\mathrm{CO}$ emissions from the biomass burning emission inventory described in Liousse et al. (2010), were used for the horizontal distribution of the tracer. An exponential decay was imposed on the $\mathrm{CO}$ tracer with a lifetime of 20 days. Even if an exponential decay was imposed and $\mathrm{CO}$ emissions were used, the biomass burning tracer is reported in arbitrary units instead of ppbv of CO because the simulation is too long to neglect chemistry.

To discuss the capability of the model to reproduce the local transport near Cotonou, Fig. 8 shows the vertical profile of wind speed, wind direction and relative humidity measured by the dropsonde launched at 10:41 UTC by the FF20 and calculated in the $8 \mathrm{~km}$-anthro simulation at 10:00, 12:00 and 14:00 UTC on 19 August above Cotonou. Measurements show the monsoon layer with a uniform southwesterly wind from ground up to $1.2 \mathrm{~km}$ and wind speed with a maximum of $10 \mathrm{~m} \mathrm{~s}^{-1}$ at $0.5 \mathrm{~km}$ and decreasing toward $0 \mathrm{~m} \mathrm{~s}^{-1}$ at $1.2 \mathrm{~km}$. BOLAM (black line, 10:00 UTC) reproduces such a layer, underestimating the maximum wind speed. Above the monsoon layer, measurements report a counter-clockwise rotation of $360^{\circ}$ of the wind between 1.2 and $2.5 \mathrm{~km}$ and then again a southwesterly wind from $2.5 \mathrm{~km}$ upward. BOLAM model is able to reproduce the vertical variation of the wind direction and the overall vertical structure of the wind, even if it underestimates wind speed above $2 \mathrm{~km}$ and, due to the finite vertical resolution, is not able to catch the sharp increase in wind speed at $2.1 \mathrm{~km}$.

Regarding relative humidity, both the measurements and BOLAM show a boundary layer extending up to $1.9 \mathrm{~km}$ with a nearly saturated atmosphere and a sharp decrease toward a value of $30 \%$ at $2.5 \mathrm{~km}$. The model shows also very little change in the vertical structure humidity profile as shown by the sonde and aircraft measurements reported in Fig. 2.

Figure 9 shows the time evolution of wind speed and wind direction from $8 \mathrm{~km}$-anthro and ECMWF AMMA reanalyses, averaged between 0 and $1 \mathrm{~km}$ and between 1.5 and $3 \mathrm{~km}$ over Cotonou. Within the monsoon layer (upper panel) BOLAM shows a high correlation with analyses concerning both wind speed and wind direction. Regarding the $1.5-3 \mathrm{~km}$ layer, where the highest differences in ozone mixing ratio were found, there is a good agreement between simulation 

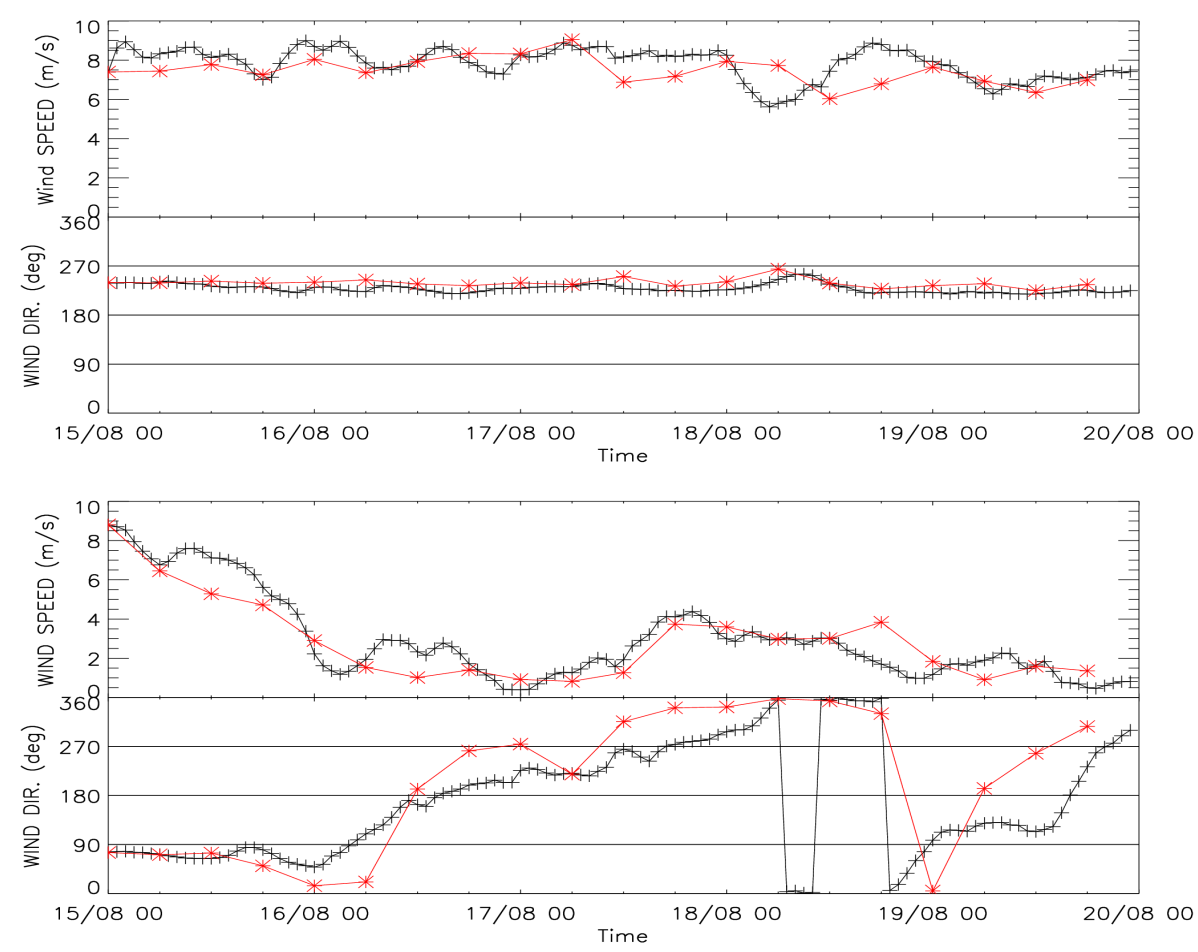

Fig. 9. Time evolution of wind speed and wind direction for the $8 \mathrm{~km}$-anthro simulation (black line) and for ECMWF AMMA re-analyses (red line) above Cotonou. Values are averaged over the $0-1 \mathrm{~km}$ (upper panels) and the $1.5-3 \mathrm{~km}$ (lower panels) altitude ranges.

and analyses during the whole simulation except for the last day, when the clockwise rotation of the wind is slower in the simulation than in the analyses. This is of small importance for the transport of anthropogenic tracer because the last day of simulation is also characterized by weak winds $\left(<2 \mathrm{~m} \mathrm{~s}^{-1}\right)$. Simulated wind fields averaged over the whole simulated period (not shown) also show a reasonable agreement with analyses in both altitude ranges within the monsoon layer.

\subsubsection{Tracer simulation results}

Figure 10 report the horizontal distribution and the vertical cross section of anthropogenic tracer concentration from $8 \mathrm{~km}$-anthro simulation. The horizontal cross section shows that the anthropogenic tracer is transported from the emission regions along the coast (pink squares in Fig. 10). Highest concentrations are related to Lagos emissions. The vertical cross section of tracer concentration shows high values at the ground near Cotonou, where there are some emissions of $\mathrm{CO}$, and a minimum around $0.9 \mathrm{~km}$ due to the southwesterly advection of air with low tracer concentrations from the ocean. Above the minimum and up to $2.8 \mathrm{~km}$, a tracer layer with maximum around $2.4 \mathrm{~km}$ is visible, in agreement with $\mathrm{O}_{3}$ and $\mathrm{CO}$ profiles influenced by Cotonou city plume (west profiles in Fig. 2). The boundary of the area influenced by anthropogenic emissions is indeed located near Cotonou at the different altitudes below $3 \mathrm{~km}$, supporting the fact that the horizontal gradient at these altitudes are related to anthropogenic emissions in the the Lagos/Cotonou area.

In Fig. 11 left panel, the $900 \mathrm{hPa}$ horizontal distribution of biomass burning tracer, from the $24 \mathrm{~km}-\mathrm{bb}$ simulation, shows that around Cotonou (red asterisk in Fig. 11) the tracer remains confined far from the coast. In Fig. 11 right panel, the vertical structure of the tracer over Cotonou (red asterisk) shows that a layer of high concentrations is present from $2.5 \mathrm{~km}$ upward. This structure agrees with the observations and also the work of Thouret et al. (2009) that reported frequent ozone enhancements above Cotonou between 3 and $5 \mathrm{~km}$ in August 2006 (see Sect. 5). At lower altitudes, the tracer remains confined far from the coast in the simulation in agreement with the observations above the ocean. Nevertheless regional simulations can fail in reproducing the position and strength of the Southern African Easterly Jet and/or the re-circulation above the continent around the equator. This may lead to an uncertainty in the transport of biomass emissions from the SH (Williams et al., 2010; Real et al., 2010).

The BOLAM results then show that the observed ozone local anomaly near Cotonou can be explained by the advection of polluted plumes from the Lagos area and that advection of biomass burning emissions is not related to the occurrence of this anomaly. 

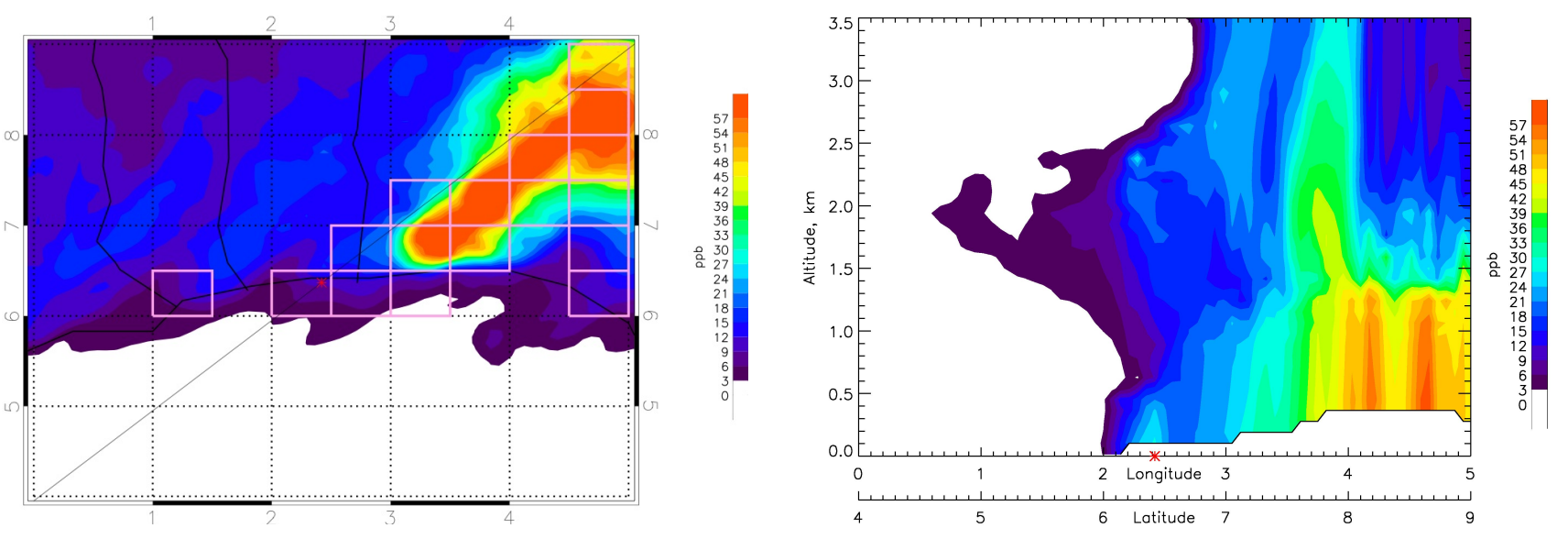

Fig. 10. Horizontal and vertical cross section of anthropogenic tracer mixing ratio in ppbv on 19 August, 13:00 UTC from the 8 km-anthro BOLAM simulation. Solid line on the $900 \mathrm{hPa}$ cross section (left panel) indicates the position of the vertical cross section (right panel). Cotonou is indicated by the red asterisk. CO emissions $>0.5 \mu \mathrm{g} \mathrm{m}^{-2} \mathrm{~s}^{-1}$ in pink squares.
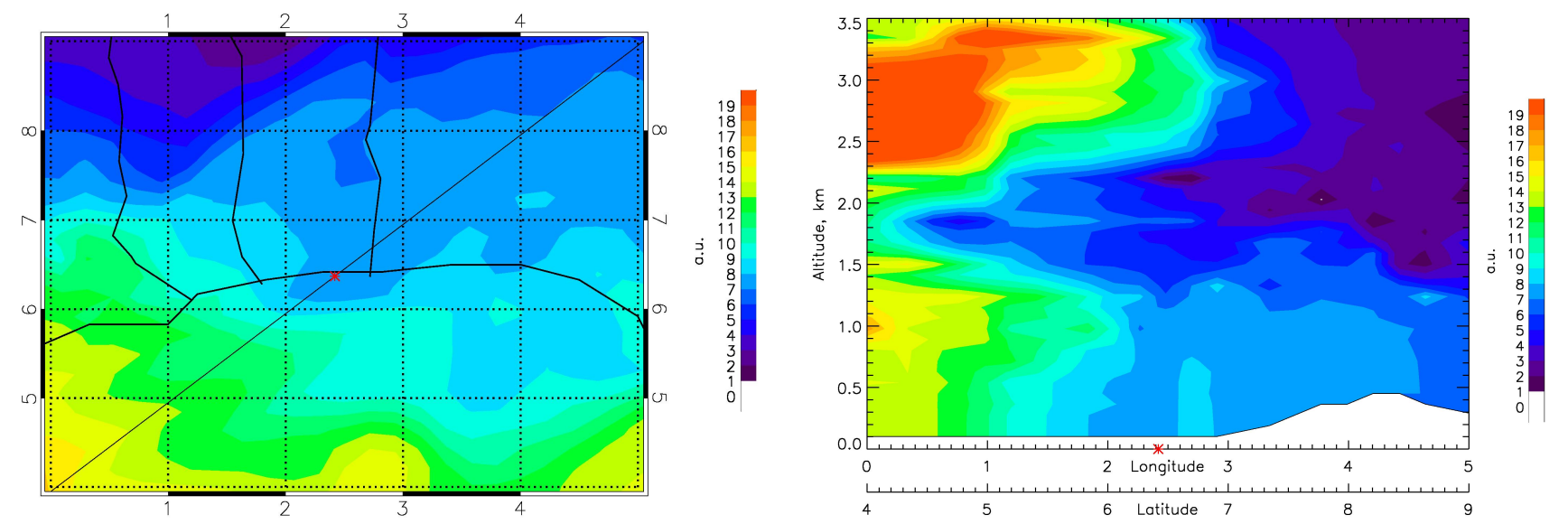

Fig. 11. Horizontal and vertical cross section of biomass burning tracer concentration in arbitrary units (see text) on 19 August, 12:00 UTC from the $24 \mathrm{~km}$-bb BOLAM simulation. Solid line on the $900 \mathrm{hPa}$ cross section (left) indicates the position of the vertical cross section (right). Cotonou is indicated by the red asterisk.

\subsection{Modelling of the ozone production}

In order to estimate if the $\mathrm{O}_{3}$ difference $>40 \mathrm{ppbv}$ between the background composition and the city plume can be produced by anthropogenic emissions in Cotonou/Lagos and $\mathrm{Ni}$ amey, the CiTTyCAT (Cambridge Tropospheric Trajectory Model of Chemistry and Transport) chemistry box model was used. It is a photochemical model including 90 chemical species (see Evans et al., 2000 for details) and has been previously used to simulate the chemical evolution in the biomass burning plume originating from central Africa and advected towards West Africa in the lower-mid troposphere in 2006 (Real et al., 2010). FLEXPART simulations (see Sects. 4.1 and 4.2) showed that air masses containing the high $\mathrm{O}_{3}$ plume had remained in the city region for at least 2 days. Meteorological conditions $24 \mathrm{~h}$ before the flight were generally characterised by low winds and no MCS, so it is a reasonable approximation to neglect mixing and wet deposition, in this case. Dry deposition is also assumed to negligible in this case since the plumes were located above $500 \mathrm{~m}$. Therefore, a 2-day stationary run was conducted using diurnal cycles of temperature and relative humidity corresponding to ground based observations collected during AMMA at this location. Near the coast, the temperature varied between $23^{\circ}$ and $27^{\circ}$ with relative humidity rangeing from $80 \%$ to $100 \%$.

Since pollutant concentrations directly emitted over the source region are unknown, FF20 observations of $\mathrm{O}_{3}$ precursors were used to initialize the model. Unfortunately, only $\mathrm{CO}$ and $\mathrm{NO}_{\mathrm{x}}$ were measured in this plume. Volatile Organic Compound (VOC) initial concentrations were estimated from the mean ratio of VOC/CO measured during the whole campaign by the BAe-146 aircraft at lower altitudes $(<3 \mathrm{~km})$, by scaling the VOC to the $\mathrm{CO}$ measured in 


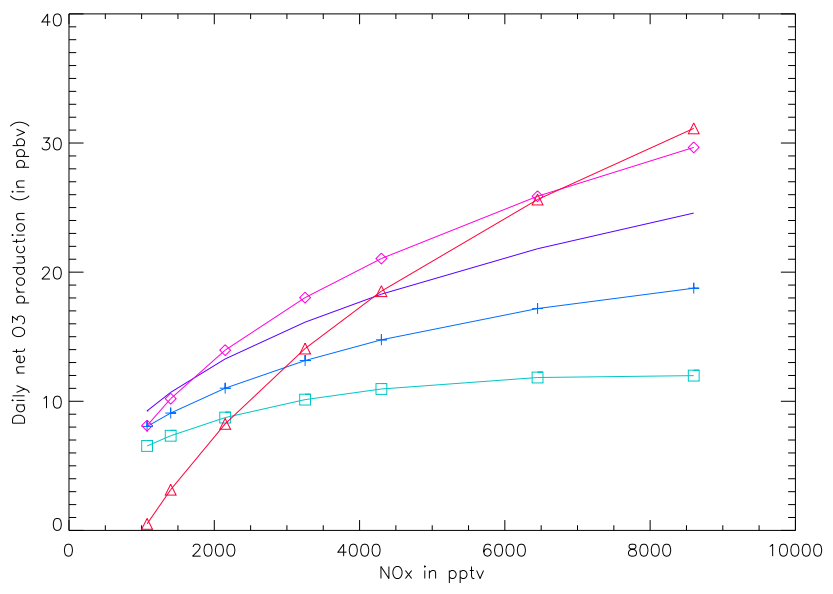

Fig. 12. Daily net $\mathrm{O}_{3}$ production simulated by the box model as a function of $\mathrm{NO}_{\mathrm{x}}$ for different VOC initialisations: green line with squares (VOC/4), blue line with crosses (VOC/2), purple line (reference $\mathrm{VOC})$, pink line with diamonds $(\mathrm{VOC} \times 2)$ and red line with triangles $(\mathrm{VOC} \times 4)$.

the high $\mathrm{O}_{3}$ plume by the FF20. To initialise $\mathrm{NO}_{\mathrm{y}}$, a typical ratio $\mathrm{NO}_{\mathrm{y}} / \mathrm{NO}_{\mathrm{x}}$ of 2 was used. This is the mean ratio measured during the campaign by the DF20 when encountering high $\mathrm{NO}_{\mathrm{x}}$ plumes. $\mathrm{NO}_{\mathrm{z}}$ concentrations $\left(\mathrm{NO}_{\mathrm{y}}-\mathrm{NO}_{\mathrm{x}}\right)$ was then partitioned between PAN and $\mathrm{HNO}_{3}$, with $\mathrm{HNO}_{3}$ and PAN being respectively $75 \%$ and $25 \%$ of $\mathrm{NO}_{\mathrm{z}}$. This partitioning corresponds to the values observed at low altitudes during the whole campaign by the BAe-146 aircraft. Ozone concentrations measured by the aircraft in the cleanest air were used to initialise the model simulations. Concentrations used in this reference polluted run are detailed in Table 4.

Maximum values of $\mathrm{NO}_{2}$ and $\mathrm{O}_{3}$ photolysis rates are respectively $9.1 \times 10^{-3} \mathrm{~s}^{-1}$ and $4.3 \times 10^{-5} \mathrm{~s}^{-1}$ around 12:00 UTC. These values are typical of photolysis rates near the equator, without any clouds (Liao et al., 1999). The model climatological data base for clouds was not used since it is not very well suited for the very complex cloud structure observed in Africa during the monsoon season. This assumption is also justified because no MCS were observed over Cotonou during the two days corresponding to the simulation. What may be missing is the aerosol impact on photolysis rates, as Fig. 11 shows that a biomass burning aerosol layer is present in the free troposphere above the city plume. Our estimation of the $\mathrm{O}_{3}$ production is therefore an upper limit since photolysis rate may be slightly overestimated.

Considering uncertainties in the $\mathrm{O}_{3}$ precursor concentrations estimated in this reference run, sensitivity tests were conducted by multiplying or dividing $\mathrm{NO}_{\mathrm{x}}$ and VOC concentrations with a factor 2 and 4. This is also justified by the fact that the aircraft measurements are representative of a processed plume, and not a very fresh plume. When the $\mathrm{NO}_{\mathrm{x}}$ concentrations were modified, the $\mathrm{NO}_{\mathrm{y}}$ concentrations were also changed using the same scaling factor between these
Table 4. Chemical initialisation of the box model reference run. Observations used to define the chosen concentrations are indicated. The BAe-146 VOC and CO measurements are average values over the AMMA region below $3 \mathrm{~km}$ and scaled to FF20 CO measurements.

\begin{tabular}{lll}
\hline Species & Origin & Values \\
\hline $\mathrm{CO}$ & FF20 city plume & $238 \mathrm{ppbv}$ \\
$\mathrm{H}_{2} \mathrm{O}_{2}$ & FF20 clean air mass & $2360 \mathrm{pptv}$ \\
$\mathrm{O}_{3}$ & FF20 clean air mass & $20 \mathrm{ppbv}$ \\
$\mathrm{CH}_{4}$ & climatological value & $1.75 \mathrm{ppm}$ \\
$\mathrm{NO}_{\mathrm{x}}$ & FF20 city plume & 1 to $8 \mathrm{ppbv}$ \\
$\mathrm{HCHO}$ & BAe-146 & $815 \mathrm{pptv}$ \\
$\mathrm{NO}_{\mathrm{y}}$ & DF20 NO $/ \mathrm{NO}_{\mathrm{x}}$ ratio & 2 to $16 \mathrm{ppbv}$ \\
$\mathrm{PAN}_{\mathrm{N}}$ & $25 \%$ of $\mathrm{NO}_{\mathrm{y}}-\mathrm{NO}_{\mathrm{x}}$ & 0.25 to $2 \mathrm{ppb}$ \\
$\mathrm{HNO}_{3}$ & $75 \%$ of $\mathrm{NO}_{\mathrm{y}}-\mathrm{NO}_{\mathrm{x}}$ & 0.75 to $6 \mathrm{ppbv}$ \\
$\mathrm{C}_{2} \mathrm{H}_{4}$ & BAe-146 & $360 \mathrm{pptv}$ \\
$\mathrm{C}_{3} \mathrm{H}_{8}$ & BAe-146 & $150 \mathrm{pptv}$ \\
$\mathrm{C}_{4} \mathrm{H}_{10}$ & BAe-146 & $45 \mathrm{pptv}$ \\
$\mathrm{C}_{5} \mathrm{H}_{12}$ & BAe-146 & $43 \mathrm{pptv}$ \\
$\mathrm{C}_{6} \mathrm{H}_{6}$ & BAe-146 & $208 \mathrm{pptv}$ \\
Ethylene & BAe-146 & $1400 \mathrm{pptv}$ \\
Propylene & BAe-146 & $74 \mathrm{pptv}$ \\
Toluene & BAe-146 & $90 \mathrm{pptv}$ \\
Isoprene & BAe-146 & $740 \mathrm{pptv}$ \\
$\mathrm{C}_{2} \mathrm{H}_{2}$ & BAe-146 & $4770 \mathrm{pptv}$ \\
MeCHO & BAe-146 & $2360 \mathrm{pptv}$ \\
\hline
\end{tabular}

two species. Daily net photochemical $\mathrm{O}_{3}$ production rates obtained from these runs are shown in Fig. 12 for the different $\mathrm{NO}_{\mathrm{x}}$ and VOC values. A value of $20 \mathrm{ppbv} \mathrm{O}_{3}$ per day, is estimated for a $\mathrm{NO}_{\mathrm{x}}$ range between 5 and $6 \mathrm{ppbv}$, already for the standard VOC concentrations. Higher VOC concentrations are needed to achieve a production rate as high as $25 \mathrm{ppbv}$ per day for the same $\mathrm{NO}_{\mathrm{x}}$ range. The dependance on $\mathrm{NO}_{\mathrm{x}}$ concentrations also increases as VOC concentrations increase. For the reference polluted concentrations and $\mathrm{NO}_{\mathrm{x}}$ near 4 ppbv, the $\mathrm{O}_{3}$ regime $\mathrm{NO}_{\mathrm{x}}$ limited since changing $\mathrm{NO}_{\mathrm{x}}$ concentrations by 2 leads to an $\mathrm{O}_{3}$ net production change twice more effective than varying VOC concentrations by 2 . Therefore, ozone production rates approaching the enhancements that were observed have been estimated, suggesting that anthopogenic plumes in this region are likely to be very photochemically active due to their high $\mathrm{NO}_{\mathrm{x}}$ concentrations.

\section{Discussion of data representativeness}

Since only one flight was analysed over Cotonou, it is difficult to estimate how often $\mathrm{O}_{3}$ is produced downwind from the city emissions. However, we can compare our data with a more extensive study of ozone vertical profiles in Cotonou by using the 24 ozone sondes record presented in Thouret et al. (2009), corresponding to the entire 2006 wet season. 
The 2006 summer mean ozone profile and the data for the sonde launched on 17 August 2006, (i.e. two days before the aircraft measurements) have a similar structure showing a positive ozone vertical gradient, but with ozone mixing ratios exceeding 50 ppbv only at altitude above $3 \mathrm{~km}$ (Fig. 13a). The fact that the mid-troposphere $\mathrm{O}_{3}$ maximum is still visible in the mean is consistent with the SH biomass burning origin of the $\mathrm{O}_{3}$ plume (Mari et al., 2008). Out of a total of 24 profiles, 8 were clearly influenced by convection (low $\mathrm{O}_{3}$ values in the upper troposphere) and 7 show a $3-$ to $5-\mathrm{km}$ $\mathrm{O}_{3}$ maximum linked to advection of biomass burning emissions. Ozone mixing ratios larger than $50 \mathrm{ppbv}$ at altitudes below $2.5 \mathrm{~km}$ are not very common in this dataset because the Cotonou ozone sonde launch site is located west of the city centre and there is a mean southwesterly flow near the coast (Fig. 1). When the wind direction shifts to an easterly flow, as for 30 June, 10:00 UT sounding, a significant $\mathrm{O}_{3}$ increase can be observed in the monsoon layer below $3 \mathrm{~km}$ (Fig. 13a) in the balloon data set. So when convection does not limit the $\mathrm{O}_{3}$ production ( $30 \%$ of the profiles) and provided $\mathrm{O}_{3}$ is measured downwind of the city, ozone values exceeding 50 ppbv can be encountered near Cotonou.

To discuss the representativeness of the Niamey aircraft data, one can use the DMI ozone sonde record obtained in Niamey from 26 July to 25 August. The $\mathrm{O}_{3}$ profiles are shown in two different figures for convective (Fig. 13b) and non-convective days (Fig. 13c) using the MCS positions and developments near Niamey as indicated by the hourly maps of the Meteosat observations available on the AMMA web site. Days with convection represented $40 \%$ of the 27 profiles. The $\mathrm{O}_{3}$ variability is larger for the days without convection and there are 3 days (10\% of all observations) with $\mathrm{O}_{3}>45 \mathrm{ppbv}$ in the $0-2 \mathrm{~km}$ altitude range. The Niamey aircraft data resemble more the $\mathrm{O}_{3}$ vertical profiles of the nonconvective days. For these days, the fraction of low $\mathrm{O}_{3}$ values $(<30 \mathrm{ppbv})$ is of the order of $50 \%$. It probably corresponds to the fraction of days with recent advection from the regions south of Niamey where $\mathrm{O}_{3}$ is reduced by deposition over the vegetation (see Fig. 7). Using the fraction of days without convection $(60 \%)$ and assuming less than $50 \%$ of the profiles with a stagnation over Niamey, puts an upper limit of $30 \%$ on the number of days where $\mathrm{O}_{3}$ enhancements.

\section{Conclusions}

Aircraft observations obtained near 3 cities in the altitude range $0-3 \mathrm{~km}$ have been examined for evidence of ozone enhancements related to anthropogenic emissions in West Africa during the wet monsoon season. Ozone mixing ratios outside the city plumes can be as low as $20 \mathrm{ppbv}$ in air masses advected at low altitudes from vegetated areas or from the ocean. Our aircraft observations showed two episodes with $\mathrm{O}_{3}$ mixing ratios exceeding $70 \mathrm{ppbv}$ in well defined plumes near the top of the PBL. To identify the good meteorological
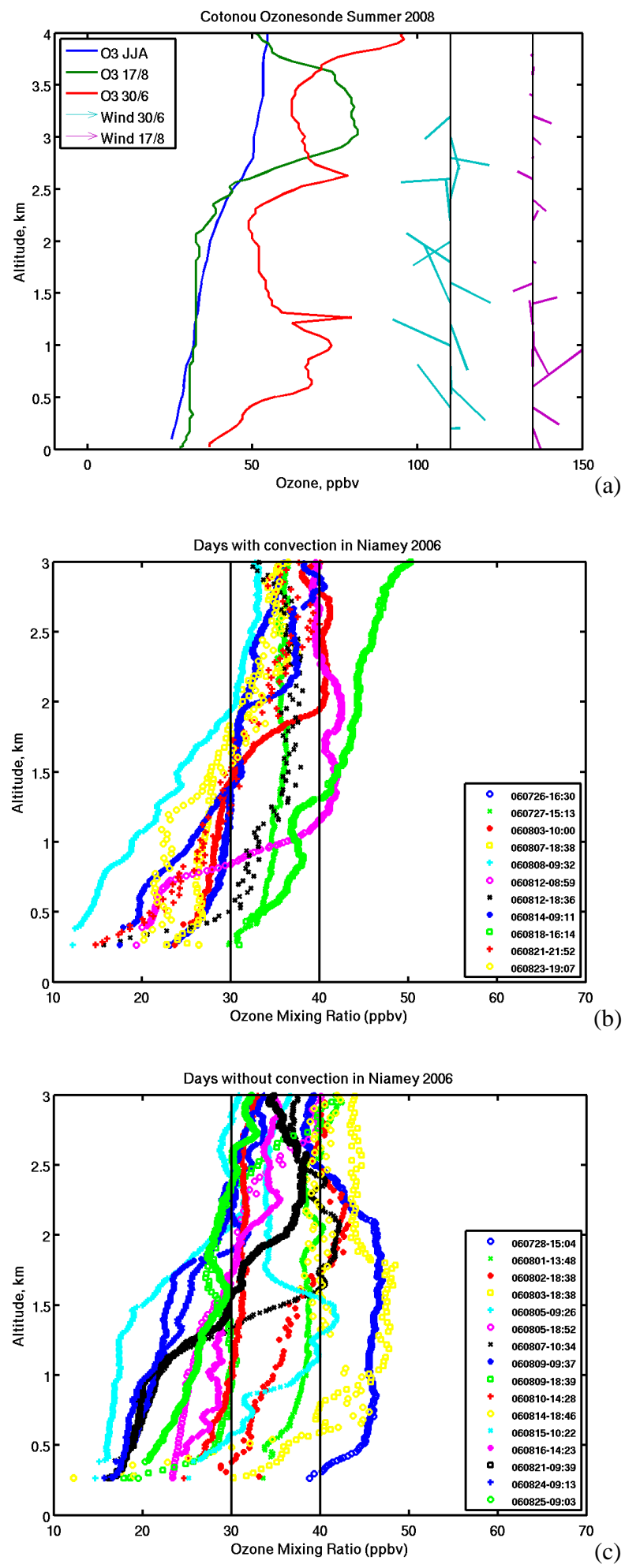

Fig. 13. (a) Three ozone sonde vertical profiles in Cotonou from Thouret et al. (2009): June/July/August mean, 17 August and 30 June 2006. Wind vector vertical profiles are shown for 17 and 30 August (the base of the wind vector is on the solid line). (b), (c) Ozone sonde vertical profiles in Niamey measured between 26 July and 25 August 2006 for days with (b) and without (c) nearby deep convection. 
conditions necessary for the formation of these $\mathrm{O}_{3}$ plumes, air mass transport was calculated with the FLEXPART model and the BOLAM mesoscale model. The BOLAM model was run with two different tracers for anthropogenic emission and biomass burning emissions to separate the ozone enhancement due to the transport of $\mathrm{SH}$ emissions and due the emissions from cities located near the observations. Both FLEXPART and BOLAM simulations show that the biomass burning plume remained above $3 \mathrm{~km}$ while the city emissions controlled the chemical composition in the $0.5-2.5 \mathrm{~km}$ altitude range. In Cotonou, it is also consistent with the $\mathrm{NO}_{\mathrm{x}}$ profile showing a maximum of $5 \mathrm{ppbv}$ near $2 \mathrm{~km}$. In Niamey $\mathrm{NO}_{\mathrm{x}}$ can only be estimated from measurements obtained at the end of the campaign, showing mixing ratios in the 35 ppbv range. Wetted bare soil $\mathrm{NO}_{\mathrm{x}}$ emissions in the Niamey latitude band during convective activity (1 to 14 August) can explain up to $1.5 \mathrm{ppbv}$ of the observed $\mathrm{NO}_{\mathrm{x}}$ according to (Delon et al., 2008) and (Stewart et al., 2008). The remaining amount of $\mathrm{NO}_{\mathrm{x}}(1.5 \mathrm{ppbv})$ must be related to the anthropogenic emissions in Niamey.

In Niamey and Ouagadougou, the daily variability of ozone and CO can be explained with the results of the FLEXPART analysis showing a correlation of ozone and $\mathrm{CO}$ enhancements for air mass stagnation near the city for 1-2 days and advection of emissions from the vegetated areas. A lack of ozone enhancements is always correlated with the occurrence of deep convection near the city identified on the METEOSAT satellite images. This explains the differences between Niamey and Ouagadougou where no ozone enhancements were observed even for elevated $\mathrm{CO}$ values. The larger vegetated area around Ouagadougou also implies a larger $\mathrm{O}_{3}$ surface eposition.

To verify that photochemical ozone production can reach 20 ppbv per day for typical $\mathrm{NO}_{\mathrm{x}}$ and $\mathrm{CO}$ conditions encountered near West African cities, simulations were carried out with the CiTTyCAT Lagrangian model and using observed average PBL chemical composition data reported by other aircraft during AMMA. Such a production is possible with $\mathrm{NO}_{\mathrm{x}}$ mixing ratios reaching $5 \mathrm{ppbv}$.

The limited number of observations makes it difficult to derive general conclusions about the role of West African cities to the $\mathrm{O}_{3}$ budget during the wet season. In fact, the main contribution of the paper is to identify the conditions needed to observe ozone enhancements related to anthropogenic city emissions. A more extensive ozone data set is available for Cotonou and Niamey when using ozonesondes. The analysis of the sonde data confirms that the very specific conditions established using the aircraft observations are also valid for the ozonesonde analysis, namely the role of convection. The analysis of the statistics of these conditions is not within the scope of this paper but could be based in future work on BOLAM simulations using tracers provided that the capability of the model to reproduce the convection variability is established. Despite the very specific conditions needed to observe ozone enhancements during the wet season, this study show that west african cities can be a substantial contributor in the ozone production balancing the efficient ozone surface deposition at the regional scale.

\section{Appendix A}

\section{Photochemical ozone production}

Many atmospheric chemistry textbooks describe the ozone photochemistry. In this appendix, the main features are very briefly discussed. Ozone can be formed in the atmosphere by chemical reaction involving $\mathrm{NO}_{\mathrm{x}}$ and non methane hydrocarbons (NMHC). The complex role of the NMHC chemistry is often simplified by considering the following cycle leading to ozone production where NMHC is abbreviated by $\mathrm{RH}$ :

$$
\begin{aligned}
& 2\left(\mathrm{NO}_{2}+h v(<430 \mathrm{~nm}) \longrightarrow \mathrm{NO}+\mathrm{O}^{3} \mathrm{P}\right) \\
& 2\left(\mathrm{O}^{3} \mathrm{P}+\mathrm{O}_{2}+\mathrm{M} \longrightarrow \mathrm{O}_{3}+\mathrm{M}\right) \\
& \mathrm{RH}+\mathrm{OH} \longrightarrow \mathrm{R}+\mathrm{H}_{2} \mathrm{O} \\
& \mathrm{R}+\mathrm{O}_{2}+\mathrm{M} \longrightarrow \mathrm{RO}_{2}+\mathrm{M} \\
& \mathrm{RO}_{2}+\mathrm{NO} \longrightarrow \mathrm{RO}+\mathrm{NO}_{2} \\
& \mathrm{RO}+\mathrm{O}_{2} \longrightarrow \mathrm{R}^{\prime} \mathrm{CHO}+\mathrm{HO}_{2} \\
& \mathrm{HO}_{2}+\mathrm{NO} \longrightarrow \mathrm{OH}+\mathrm{NO}_{2}
\end{aligned}
$$

In absence of RH oxidation by $\mathrm{OH}, \mathrm{O}_{3}$ is converted back to $\mathrm{O}_{2}$ through its reaction with $\mathrm{NO}$ and through its photolysis, then leading to a null cycle. Without $\mathrm{NO}_{\mathrm{x}}$, ozone reacts with $\mathrm{HO}_{2}$ to recycle $\mathrm{OH}$ and ozone is chemically destroyed. This is why $\mathrm{NO}_{\mathrm{x}}$ and $\mathrm{RH}$ are considered as ozone precursors. The $\mathrm{NO}_{2}$ lifetime in the atmosphere depends on the conversion of $\mathrm{NO}_{2}$ to other form of reactive nitrogen like $\mathrm{HNO}_{3}$, its major oxidation product:

$$
\begin{aligned}
& \mathrm{NO}_{2}+\mathrm{OH}+\mathrm{M} \longrightarrow \mathrm{HNO}_{3}+\mathrm{M} \\
& \mathrm{HNO}_{3}+h v(<320 \mathrm{~nm}) \longrightarrow \mathrm{NO}_{2}+\mathrm{OH}
\end{aligned}
$$

The loss of the total reactive nitrogen, often called $\mathrm{NO}_{\mathrm{y}}$, is then important for the net $\mathrm{O}_{3}$ production rate as it implies a true loss of $\mathrm{NO}_{\mathrm{x}}$. The $\mathrm{NO}_{\mathrm{y}}$ loss is mainly related to wet and dry deposition.

Acknowledgements. Based on a French initiative, AMMA was built by an international scientific group and is currently funded by a large number of agencies, especially from France, the UK, the US and Africa. The UMS SAFIRE is acknowledged for supporting the FF20 aircraft deployment and for providing the aircraft meteorological data (humidity and dropsondes). This work was supported by the AMMA EC project and CNRS/INSU. Frank Roux (Laboratoire d'Arologie) is acknowledged for work on flight planning and validation of the dropsonde data. C. Reeves (UEA Norwich) and the BAe-146 scientific team are acknowledged for 
providing the BAe VOC measurements used in the CittyCAT simulation. A. Stohl (NILU) and ECMWF are acknowledged for providing the FLEXPART model and the meteorological analyses.

Edited by: F. Keutsch

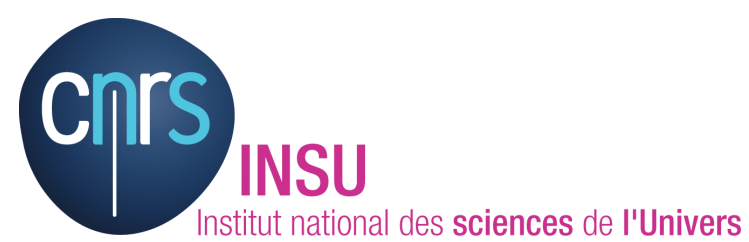

The publication of this article is financed by CNRS-INSU.

\section{References}

Aghedo, A. M., Schultz, M. G., and Rast, S.: The influence of African air pollution on regional and global tropospheric ozone, Atmos. Chem. Phys., 7, 1193-1212, doi:10.5194/acp-7-11932007, 2007.

Agusti-Panareda, A., Beljaars, A., Genkova, I., Cardinali, C., and Thorncroft, C.: Impact of assimilating AMMA soundings on ECMWF analyses and forecasts, Tech. rep., ECMWF Technical Memorandum, 2009.

Ancellet, G., Leclair de Bellevue, J., Mari, C., Nedelec, P., Kukui, A., Borbon, A., and Perros, P.: Effects of regional-scale and convective transports on tropospheric ozone chemistry revealed by aircraft observations during the wet season of the AMMA campaign, Atmos. Chem. Phys., 9, 383-411, doi:10.5194/acp-9-3832009, 2009.

Andreae, M. and Merlet, P.: Emission of Trace Gases and Aerosols From Biomass Burning, Global Biogeochem. Cy., 15, 955-966, doi:10.1029/2000GB001382, 2001.

Baehr, J., Schlager, H., Ziereis, H., Stock, P., Velthoven, P. V., Busen, R., Ström, J., and Schumann, U.: Aircraft observations of $\mathrm{NO}, \mathrm{NO}_{\mathrm{y}} \mathrm{CO}$, and $\mathrm{O}_{3}$ in the upper troposphere from $60^{\circ} \mathrm{N}$ to $60^{\circ} \mathrm{S}$ - Interhemispheric differences at mitlatitudes, Geophys. Res. Lett., 30, 1598-1601, doi:10.1029/2003GL016935, 2003.

Baumbach, G., Vogt, U., Hein, K. R. G., Oluwole, A. F., Ogunsola, O. J., Olaniyi, H. B., and Akeredolu, F. A.: Air pollution in a large tropical city with a high traffic density - results of measurements in Lagos, Nigeria, Sci. Total Environ., 169, 25-31, doi:10.1016/0048-9697(95)04629-F, 1995.

Chatfield, R. and Delany, A.: Convection Links Biomass Burning to Increased Tropical Ozone: However, Models Will Tend to Overpredict $\mathrm{O}_{3}$, J. Geophys. Res., 95, 18473-18488, doi:10.1029/JD095iD11p18473, 1990.

Colette, A. and Ancellet, G.: Variability of the tropospheric mixing and of streamer formation and their impact on the lifetime of observed ozone layers, Geophys. Res. Lett., 33, L09808, doi:10.1029/2006GL025793, 2006.

Delon, C., Reeves, C. E., Stewart, D. J., Serça, D., Dupont, R., Mari, C., Chaboureau, J.-P., and Tulet, P.: Biogenic nitrogen oxide emissions from soils - impact on $\mathrm{NO}_{\mathrm{x}}$ and ozone over West Africa during AMMA (African Monsoon Multidisciplinary Experiment): modelling study, Atmos. Chem. Phys., 8, 2351-2363, doi:10.5194/acp-8-2351-2008, 2008.
Derognat, C., Beekmann, M., Baeumle, M., Martin, D., and Schmidt, H.: Effect of biogenic volatile organic compound emissions on tropospheric chemistry during the Atmospheric Pollution Over the Paris Area (ESQUIF) campaign in the Ile-de-France region, J. Geophys. Res., 108, 8560-8574, doi:10.1029/2001JD001421, 2003.

Evans, M. J., Shallcross, D. E., Law, K. S., Wild, J. O. F., Simmonds, P. G., Spain, T. G., Berrisford, P., Methven, J., Lewis, A. C., McQuaid, J. B., Pillinge, M. J., Bandyf, B. J., Penkett, S. A., and Pyle, J. A.: Evaluation of a Lagrangian box model using field measurements from EASE (Eastern Atlantic Summer Experiment) 1996, Atmos. Environ., 34, 3843-3863, doi:10.1016/S1352-2310(00)00184-9, 2000.

Grant, D. D., Fuentes, J. D., DeLonge, M. S., Chan, S., Joseph, E., Kucera, P., Ndiaye, S. A., and Gaye, A. T.: Ozone transport by mesoscale convective storms in western Senegal, Atmos. Environ., 42, 7104-7114, doi:10.1016/j.atmosenv.2008.05.044, 2008.

Guenther, A., Karl, T., Harley, P., Wiedinmyer, C., Palmer, P. I., and Geron, C.: Estimates of global terrestrial isoprene emissions using MEGAN (Model of Emissions of Gases and Aerosols from Nature), Atmos. Chem. Phys., 6, 3181-3210, doi:10.5194/acp-63181-2006, 2006.

Hopkins, J. R., Evans, M. J., Lee, J. D., Lewis, A. C., H Marsham, J., McQuaid, J. B., Parker, D. J., Stewart, D. J., Reeves, C. E., and Purvis, R. M.: Direct estimates of emissions from the megacity of Lagos, Atmos. Chem. Phys., 9, 8471-8477, doi:10.5194/acp9-8471-2009, 2009.

Huntrieser, H., Schumann, U., Schlager, H., Höller, H., Giez, A., Betz, H.-D., Brunner, D., Forster, C., Pinto Jr., O., and Calheiros, R.: Lightning activity i n Brazilian thunderstorms during TROCCINOX: implications for $\mathrm{NO}_{\mathrm{x}}$ production, Atmos. Chem. Phys., 8, 921-953, doi:10.5194/acp-8-921-2008, 2008.

Kain, J. S.: The Kain-Fritsch Convective Parameterization: An Update, J. Appl. Meteorol., 43, 170-181, doi:10.1175/15200450(2004)043<0170:TKCPAU>2.0.CO;2, 2004.

Liao, H., Yung, Y. L., and Seinfield, J. H.: Effect of aerosol on tropospheric photolysis rates in clear and cloudy atmospheres, J. Geophys. Res., 104, 23697-23707, doi:10.1029/1999JD900409, 1999.

Liousse, C., Guillaume, B., Grégoire, J. M., Mallet, M., Galy, C., Pont, V., Akpo, A., Bedou, M., Castéra, P., Dungall, L., Gardrat, E., Granier, C., Konaré, A., Malavelle, F., Mariscal, A., Mieville, A., Rosset, R., Serça, D., Solmon, F., Tummon, F., Assamoi, E., Yoboué, V., and Van Velthoven, P.: Updated African biomass burning emission inventories in the framework of the AMMAIDAF program, with an evaluation of combustion aerosols, Atmos. Chem. Phys., 10, 9631-9646, doi:10.5194/acp-10-96312010, 2010.

Malguzzi, P., Grossi, G., Buzzi, A., Ranzi, R., and Buizza, R.: The 1966 "century" flood in Italy: A meteorological and hydrological revisitation, J. Geophys. Res., 111, D24106, doi:10.1029/2006JD007111, 2006.

Mari, C. H., Cailley, G., Corre, L., Saunois, M., Attié, J. L., Thouret, V., and Stohl, A.: Tracing biomass burning plumes from the Southern Hemisphere during the AMMA 2006 wet season experiment, Atmos. Chem. Phys., 8, 3951-3961, doi:10.5194/acp-8-3951-2008, 2008. 
Mauzerall, D. L., Logan, J. A., Jacob, D. J., Anderson, B. E., Blake, D. R., Bradshaw, J. D., Haikes, B., Sachse, G. W., Singh, H., and Talbot, B.: Photochemistry in biomass burning plumes and implications for tropospheric ozone over the tropical South Atlantic, J. Geophys. Res., 103, 8401-8423, doi:10.1029/97JD02612, 1998.

Minga, A., Thouret, V., Saunois, M., Delon, C., Serça, D., Mari, C., Sauvage, B., Mariscal, A., Leriche, M., and Cros, B.: What caused extreme ozone concentrations over Cotonou in December 2005?, Atmos. Chem. Phys., 10, 895-907, doi:10.5194/acp-10895-2010, 2010.

Parker, D., Burton, R., Diongue-Niang, A., Ellis, R., Felton, M., Taylor, C., Thorncroft, C., Bessemoulin, P., and Tompkins, A.: The diurnal cycle of the West African monsoon circulation, Q. J. Roy. Meteorol. Soc., 131, 2839-2860, doi:10.1256/qj.04.52, 2005.

Real, E., Orlandi, E., Law, K. S., Fierli, F., Josset, D., Cairo, F., Schlager, H., Borrmann, S., Kunkel, D., Volk, C. M., McQuaid, J. B., Stewart, D. J., Lee, J., Lewis, A. C., Hopkins, J. R., Ravegnani, F., Ulanovski, A., and Liousse, C.: Cross-hemispheric transport of central African biomass burning pollutants: implications for downwind ozone production, Atmos. Chem. Phys., 10, 3027-3046, doi:10.5194/acp-10-3027-2010, 2010.

Reeves, C. E., Formenti, P., Afif, C., Ancellet, G., Attié, J.-L., Bechara, J., Borbon, A., Cairo, F., Coe, H., Crumeyrolle, S., Fierli, F., Flamant, C., Gomes, L., Hamburger, T., Jambert, C., Law, K. S., Mari, C., Jones, R. L., Matsuki, A., Mead, M. I., Methven, J., Mills, G. P., Minikin, A., Murphy, J. G., Nielsen, J. K., Oram, D. E., Parker, D. J., Richter, A., Schlager, H., Schwarzenboeck, A., and Thouret, V.: Chemical and aerosol characterisation of the troposphere over West Africa during the monsoon period as part of AMMA, Atmos. Chem. Phys., 10, 7575-7601, doi:10.5194/acp-10-7575-2010, 2010.

Sanderson, M. G., Dentener, F. J., Fiore, A. M., Cuvelier, C., Keating, T. J., Zuber, A., Atherton, C. S., Bergmann, D. J., Diehl, T., Doherty, R. M., Duncan, B. N., Hess, P., Horowitz, L. W., Jacob, D. J., Jonson, J.-E., Kaminski, J. W., Lupu, A., MacKenzie, I. A., Mancini, E., Marmer, E., Park, R., Pitari, G., Prather, M. J., Pringle, K. J., Schroeder, S., Schultz, M. G., Shindell, D. T., Szopa, S., Wild, O., and Wind, P.: A multi-model study of the hemispheric transport and deposition of oxidised nitrogen, Geophys. Res. Lett., 35, L17815, doi:10.1029/2008GL035389, 2008.

Saunois, M., Reeves, C. E., Mari, C. H., Murphy, J. G., Stewart, D. J., Mills, G. P., Oram, D. E., and Purvis, R. M.: Factors controlling the distribution of ozone in the West African lower troposphere during the AMMA (African Monsoon Multidisciplinary Analysis) wet season campaign, Atmos. Chem. Phys., 9, 61356155, doi:10.5194/acp-9-6135-2009, 2009.

Sauvage, B., Gheusi, F., Thouret, V., Cammas, J.-P., Duron, J., Escobar, J., Mari, C., Mascart, P., and Pont, V.: Medium-range midtropospheric transport of ozone and precursors over Africa: two numerical case studies in dry and wet seasons, Atmos. Chem. Phys., 7, 5357-5370, doi:10.5194/acp-7-5357-2007, 2007a.
Sauvage, B., Martin, R., van Donkelaar, A., and Ziemke, J.: Quantification of the factors controlling tropical tropospheric ozone and the South Atlantic maximum, J. Geophys. Res., 112, D11309-D11322, doi:10.1029/2006JD008008, 2007b.

Schultz, P.: An Explicit Cloud Physics Parameterization for Operational Numerical Weather Prediction, Mon. Weather Rev., 123, 3331-3343, doi:10.1175/15200493(1995)123<3331:AECPPF> 2.0.CO;2, 1995.

Schumann, U. and Huntrieser, H.: The global lightning-induced nitrogen oxides source, Atmos. Chem. Phys., 7, 3823-3907, doi:10.5194/acp-7-3823-2007, 2007.

Stewart, D. J., Taylor, C. M., Reeves, C. E., and McQuaid, J. B.: Biogenic nitrogen oxide emissions from soils: impact on $\mathrm{NO}_{\mathrm{x}}$ and ozone over west Africa during AMMA (African Monsoon Multidisciplinary Analysis): observational study, Atmos. Chem. Phys., 8, 2285-2297, doi:10.5194/acp-8-2285-2008, 2008.

Stohl, A., Hittenberger, M., and Wotawa, G.: Validation of the lagrangian particle dispersion model FLEXPART against largescale tracer experiment data, Atmos. Environ., 32, 4245-4264, doi:10.1016/S1352-2310(98)00184-8, 1998.

Stohl, A., Eckhardt, S., Forster, C., James, P., Spichtinger, N., and Seibert, P.: A replacement for simple back trajectory calculations in the interpretation of atmospheric trace substance measurements, Atmos. Environ., 36, 4635-4648, doi:10.1016/S13522310(02)00416-8, 2002.

Thompson, A., Doddridge, B., Witte, J., Hudson, R., Luke, W., Johnson, J. E., Johnson, B., Oltmans, S., and Weller, R.: A tropical Atlantic paradox: Shipboard and satellite views of a tropospheric ozone maximum and wave-one in January-February 1999, Geophys. Res. Lett., 27, 3317-3320, doi:10.1029/1999GL011273, 2000.

Thouret, V., Saunois, M., Minga, A., Mariscal, A., Sauvage, B., Solete, A., Agbangla, D., Nédélec, P., Mari, C., Reeves, C. E., and Schlager, H.: An overview of two years of ozone radio soundings over Cotonou as part of AMMA, Atmos. Chem. Phys., 9, 6157-6174, doi:10.5194/acp-9-6157-2009, 2009.

Tompkins, A., Diongue-Niang, A., Parker, D., and Thorncroft, C.: The African easterly jet in the ECMWF Integrated Forecast System: 4D-Var analysis, Q. J. Roy. Meteorol. Soc., 131, 28612885, doi:10.1256/qj.04.136, 2005.

Vizy, E. K. and Cook, K. H.: Development and application of a mesoscale climate model for the tropics: Influence of sea surface temperature anomalies on the West African monsoon, J. Geophys. Res., 107, 4023-4044, doi:10.1029/2001JD000686, 2002.

Williams, J. E., Scheele, R., Van Velthoven, P., Bouarar, I., Law, K., Josse, B., Peuch, V. H., Yang, X., Pyle, J., Thouret, V., Barret, B., Liousse, C., Hourdin, F., Szopa, S., and Cozic, A.: Global Chemistry Simulations in the AMMA Multimodel Intercomparison Project, B. Am. Meteorol. Soc., 91, 611-624, doi:10.1175/2009BAMS2818.1, 2010.

Zampieri, M., Malguzzi, P., and Buzzi, A.: Sensitivity of quantitative precipitation forecasts to boundary layer parameterization: a flash flood case study in the Western Mediterranean, Nat. Hazards Earth Syst. Sci., 5, 603-612, doi:10.5194/nhess-5-6032005, 2005. 